\title{
Long-term care: a review of global funding models
}

\author{
S. Elliott*, S. Golds, I. Sissons and H. Wilson
}

[Presented to the Institute and Faculty of Actuaries Edinburgh: 17 March 2014]

\begin{abstract}
This paper looks at alternative long-term care (LTC) funding models and options. It analyses six global models and the potential applications to the United Kingdom. The paper provides a demographic overview for each of the six countries to illustrate the increasing global demand for LTC and the funding thereof that is becoming a global critical issue. It examines the approaches each country has taken to address the funding issue with varying degrees of public/private co-operation and partnerships. The authors hope that the lessons learned from these other markets will assist the United Kingdom as they try to come to grips with their growing social care funding issue.
\end{abstract}

\section{Keywords}

Long-Term Care; Public/Private Partnerships; Health and Social Care; Self-Funders

\section{Introduction}

\subsection{Background}

1.1.1. The paper will be looking at alternative long-term care (LTC) funding models and options around the globe. It will analyse six countries separately and then look at the potential applications for the UK market.

1.1.2. LTC in the main refers to the support provided to the elderly as they lose the ability to look after themselves. It is a combination of medical, nursing, custodial, social and community services designed to help people who have disabilities or chronic care needs, including dementia. Services may be provided in the person's home (i.e. domiciliary), in the community, in assisted living facilities or in care homes.

1.1.3. Longevity is increasing as a result of advances in medical technology and treatments. People are living longer but potentially in a more disabled state.

1.1.4. The demand for LTC and the funding thereof is increasing globally. Countries are at various stages of this demand and they have taken different approaches to satisfy this demand.

1.1.5. Countries need to design programmes that provide independence and financial security for their elderly. This will involve varying degrees of public/private partnership and co-operation.

1.1.6. The six countries that are included in the analysis are France, Germany, Japan, the Netherlands, United Kingdom and United States.

*Correspondence to: Sue Elliott, Health \& Protection. Tel: +44 (0)780 1247 831. E-mail: s-elliott9@sky.com 


\subsection{Structure of the Paper}

1.2.1. This first section provides some background on the growing LTC crisis around the globe.

1.2.2. Section 2 provides a geographic overview comparing the six countries including demographic trends, social changes and healthcare expenditure.

1.2.3. Section 3 provides more details at a country-specific level that includes more details on the demographics, public systems, private systems, partnerships and lessons learned.

1.2.4. Section 4 provides an overview of the UK market and potential overseas applications to the United Kingdom.

1.2.5. Section 5 sets out the conclusions of our research and analysis and potential next steps.

1.2.6. Section 6 provides a glossary and summary of abbreviations used in the paper, which the reader may find useful.

1.2.7. Section 7 provides the references we used for the research and analysis in our paper.

\section{Geographic Overview}

2.1. This section sets out a comparison of demographic trends, social changes and healthcare expenditure for each of the six countries (where data were available). The countries were chosen either because they were deemed to be relatively successful in the private Long-Term Care Insurance (LTCI) market or for their extremes in public versus private partnership.

\subsection{Demographic Trends}

\subsubsection{Population projections}

- Figures 1 and 2 illustrate the projected demographic pressure as the global population ages.

- Japan has the greatest proportion age $65+$ in 2010 at $23 \%$. It also has the greatest projected growth where the proportion is projected to almost double by 2050. In contrast the United States has the lowest current proportion age $65+$ population and the lowest projected growth. In 2010 the range, across the six countries, is from $13 \%$ to $23 \%$ and the projected range for 2050 is from $21 \%$ to $40 \%$.

- The results for age $85+$ are similar with Japan having the highest proportion and the United States having the lowest. In 2010 the range, across the six countries, is from $2 \%$ to $8 \%$ and the projected range by 2050 from $5 \%$ to $12 \%$.

2.2.2. Life expectancy trends

- Figures $3 \mathrm{a}$ and $\mathrm{b}$ illustrate the increase in life expectancy over the 20 years from 1990 to 2010 .

- For females at birth the United States has the lowest starting at age 79 in 1990 and increasing to age 81 in 2010. In contrast, Japan has the highest increasing from age 82 in 1990 to age 86 in 2010. The United Kingdom has the second lowest life expectancy for the six countries analysed. 


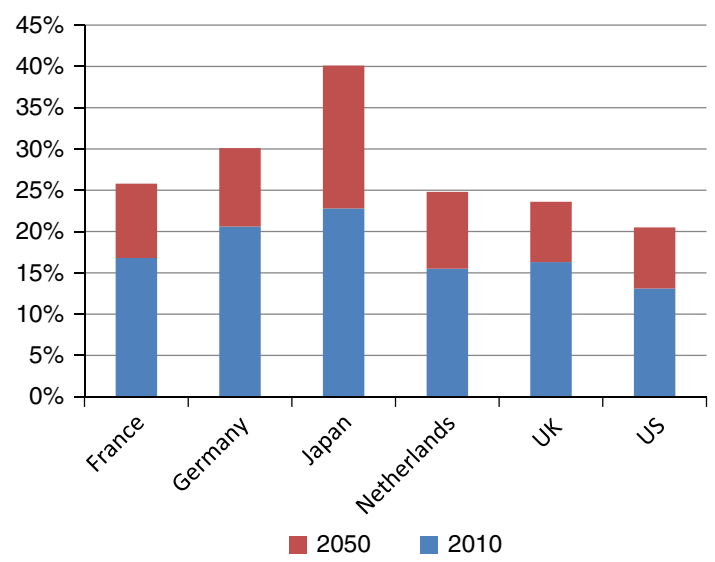

Figure 1. Projected population age $65+$ ( $\%$ of total population) Source: US Census Bureau, international database.

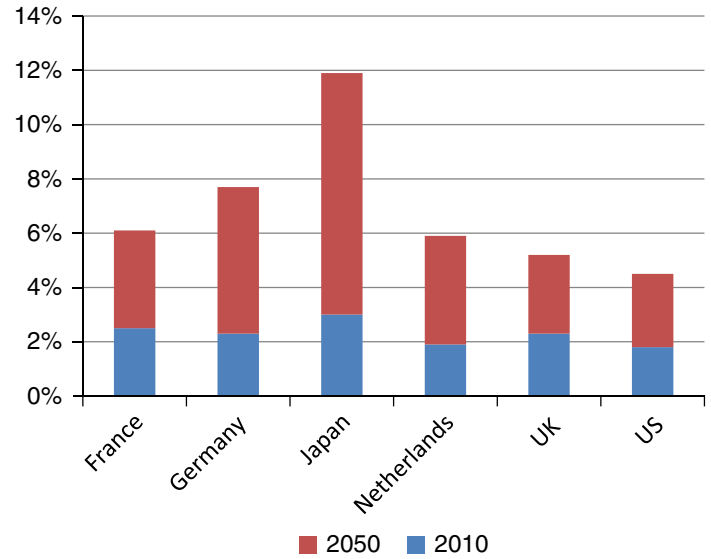

Figure 2. Projected population age $85+$ (\% of total population) Source: US Census Bureau, international database.

- At age 65 the range is not as great as at birth. Japan and France are the highest at about 20 years in 1990 increasing to about 23 years in 2010. The remaining countries are grouped below them at about 2-3 years less.

- For males the overall life expectancy at birth is about 5-7 years lower than females and at age 65 about 3-5 years lower than females. This gap may however be narrowing.

\subsubsection{Population pyramids}

- Figures 4-9 set out population pyramids for each of the six countries for 2010 and 2050 (projected). The source for all of the charts is from the US Census Bureau, international database. Ages 45-60 represent the "baby boomers" that will be moving to the top of the pyramids and hence making them appear "top heavy".

- The projected increase in the elderly population is most pronounced for Japan. 
(a)

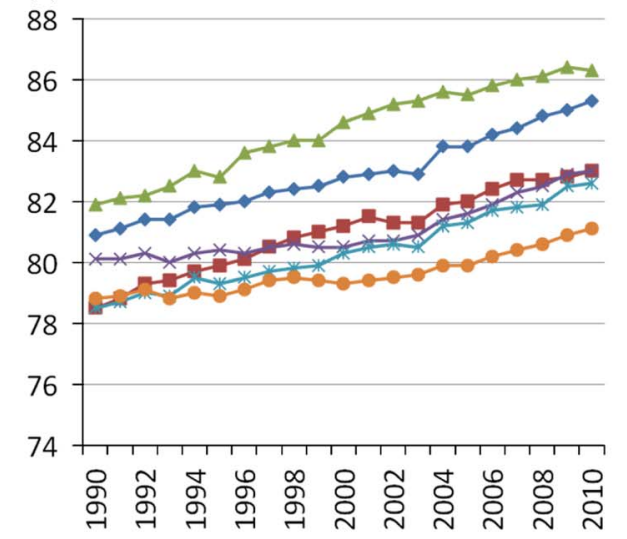

$\rightarrow$ France $\rightarrow$ - Germany $\leftarrow$ Japan

$*$ Netherlands $*$ UK $\rightarrow$ US

(b)

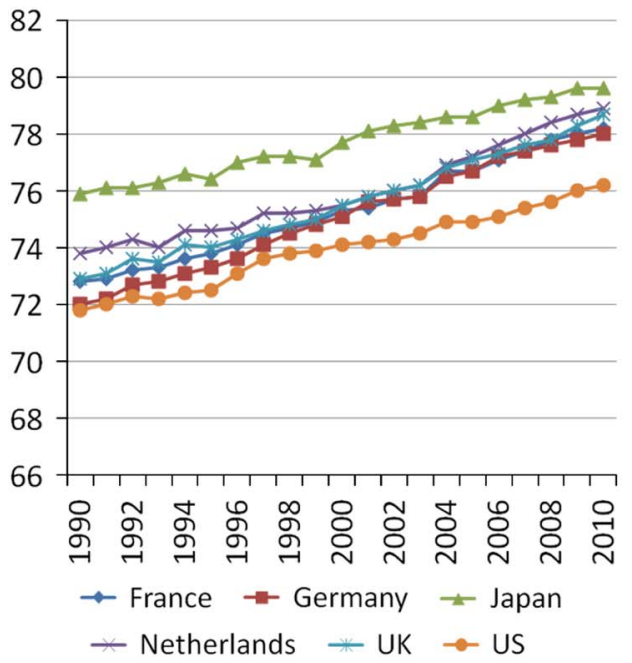

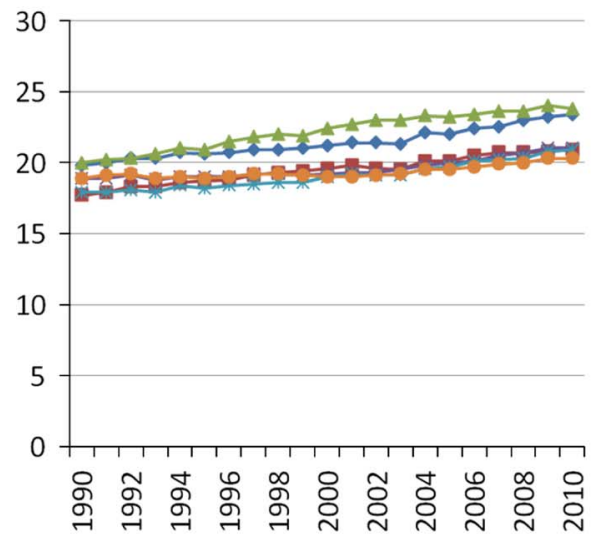

$\rightarrow$ France $\rightarrow$ Germany $\rightarrow$ Japan

* Netherlands $*$ UK $\rightarrow$ US

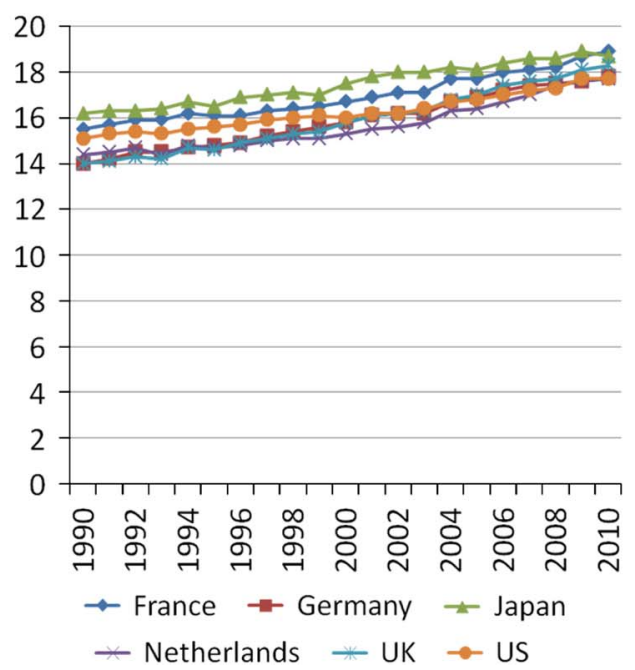

Figure 3. (a) Female life expectancy at birth and age 65. (b) Male life expectancy at birth and age 65 Source: OECD stat extracts.

\subsubsection{Dependency ratios}

- The dependency ratio measures how much the elderly population is dependent on the working age population. It is defined as:

$$
\text { Dependency ratio }(\%)=\text { age } 65+\text { /ages } 15-64
$$

- Figure 10 illustrates how the dependency ratio has increased over time from 1960 to 2008 for all six countries. As the age 65+ age group increases and the age 15-64 age group decreases it means there are fewer working age population to support the increasing elderly population. Japan had the most significant increase from $9 \%$ in 1960 to $37 \%$ in 2008 (just over four times). The United States showed the slowest growth. 

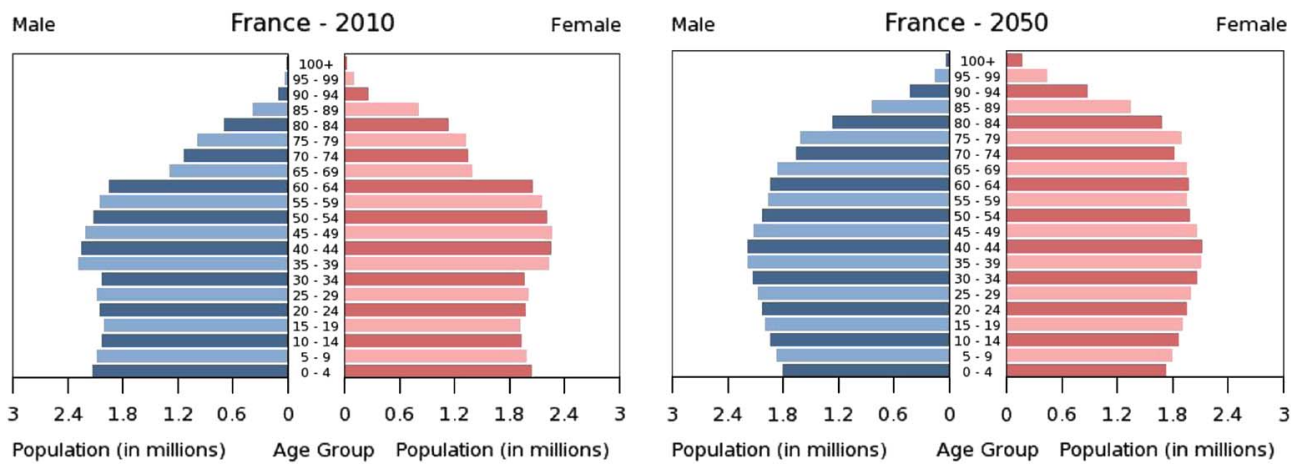

Figure 4. Population pyramid (France)
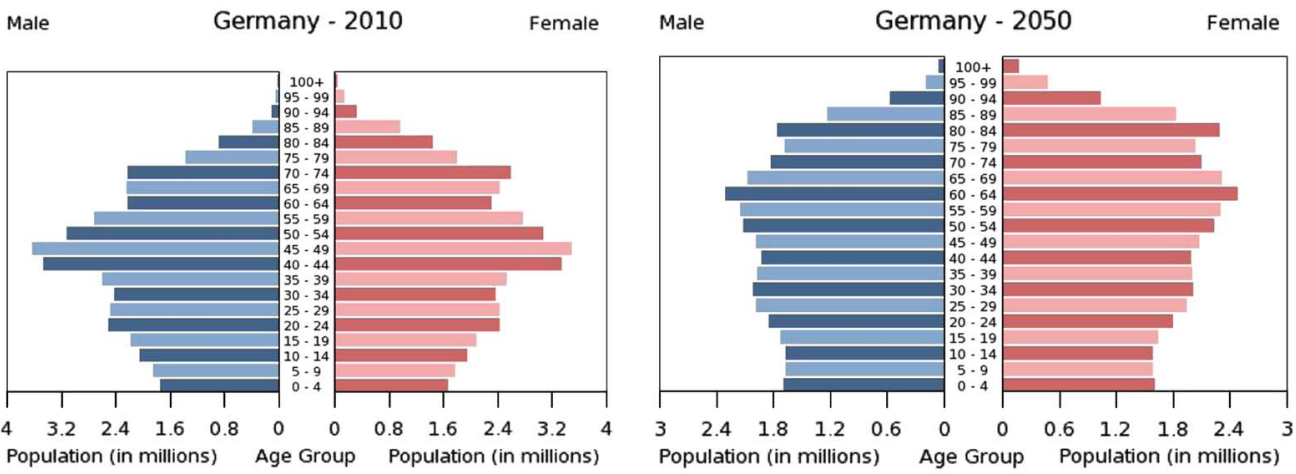

Figure 5. Population pyramid (Germany)
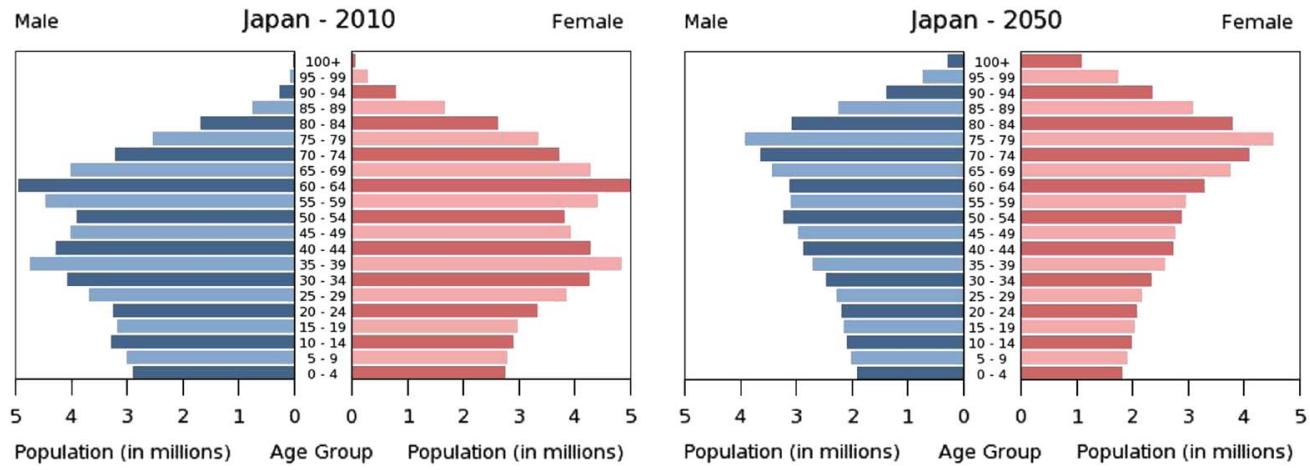

Figure 6. Population pyramid (Japan)

\subsection{Social Changes}

2.3.1. Figures 11 and 12 show a decline in marriage rates and an increase in divorce rates which means an increasing number of non-married people. As a result more elderly people may be living on their own and having to rely on care from professional caregivers as opposed to care from a spouse (assuming informal care from another family member or friend is not available). 

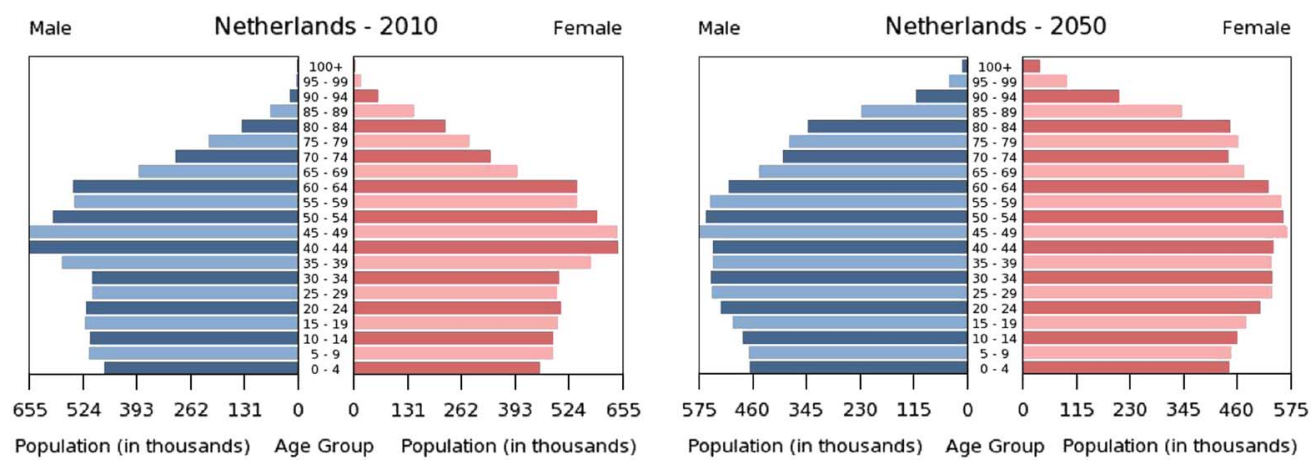

Figure 7. Population pyramid (the Netherlands)
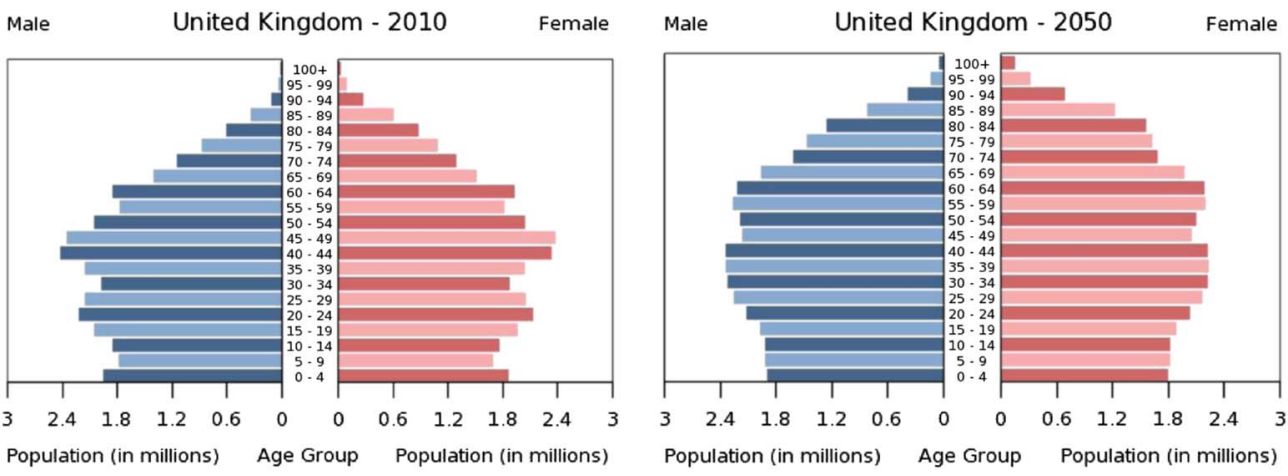

Figure 8. Population pyramid (United Kingdom)
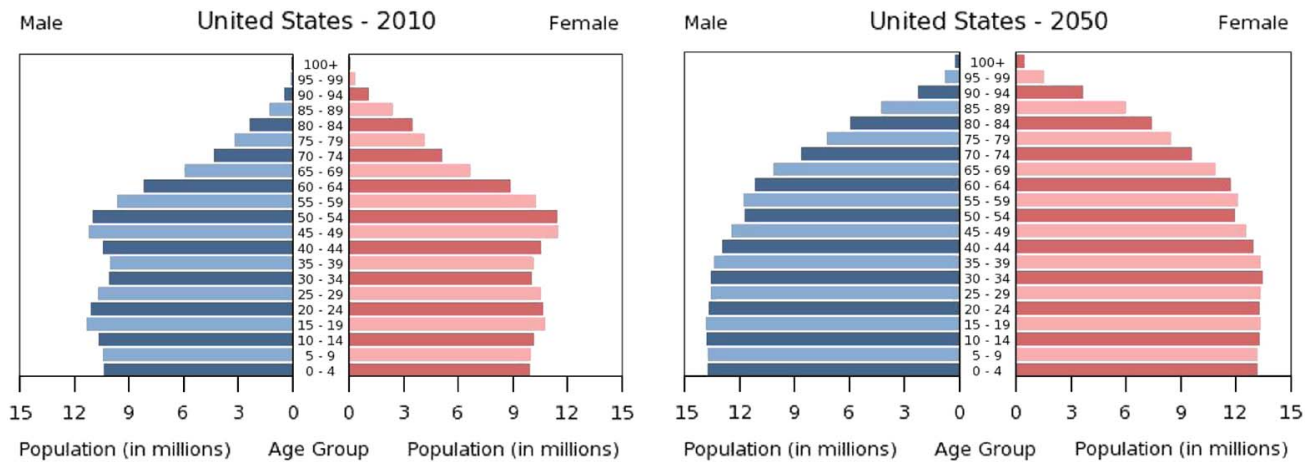

Figure 9. Population pyramid (United States)

\subsection{Expenditure on Healthcare and LTC}

Figure 13 shows that France and the Netherlands are all publically funded; whereas, Japan, Germany and the United States are $86 \%, 71 \%$ and $59 \%$ publically funded, respectively. Comparable UK data were not available. However, as per "fairer care funding - analysis and evidence, figure 1.2, July 2011 ", the $2009 / 2010$ care expenditure was $£ 7.5$ million for public and $£ 8.3$ million for private. 


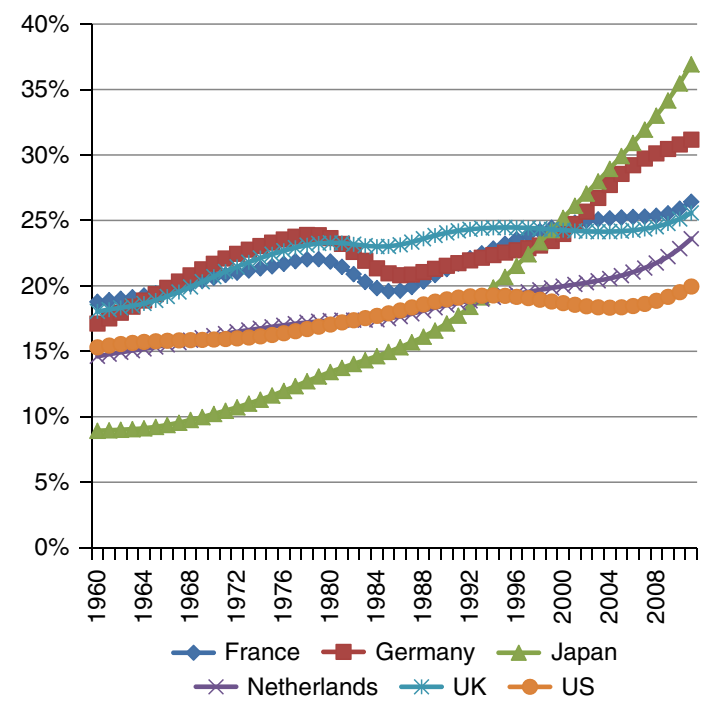

Figure 10. Dependency ratios Source: World Bank Group, WDI Online.

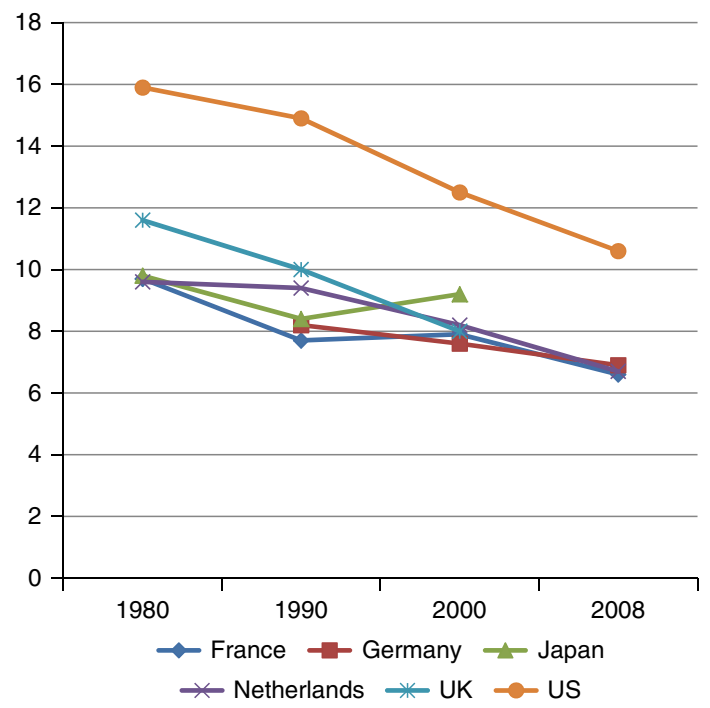

Figure 11. Marriage rates (per 1,000; ages 15-64)

Source: US Census Bureau, statistical abstract of the US, 2012.

In addition, the proportion of private expenditure has increased for France since these 2009 statistics were published with take up rates being about $15 \%$.

2.4.2. Figure 14 shows that LTC expenditure as a percentage of total healthcare expenditure ranges from as low as $7 \%$ (i.e. $0.6 / 8.4$ ) in the United States to as high as $28 \%$ (i.e. $2.7 / 9.5$ ) in the Netherlands. For the UK healthcare expenditure was $8.0 \%$ of gross domestic product (GDP) and LTC expenditure was $1.2 \%$ of GDP based on the "Economic \& fiscal outlook, office of budget responsibility 2010". 


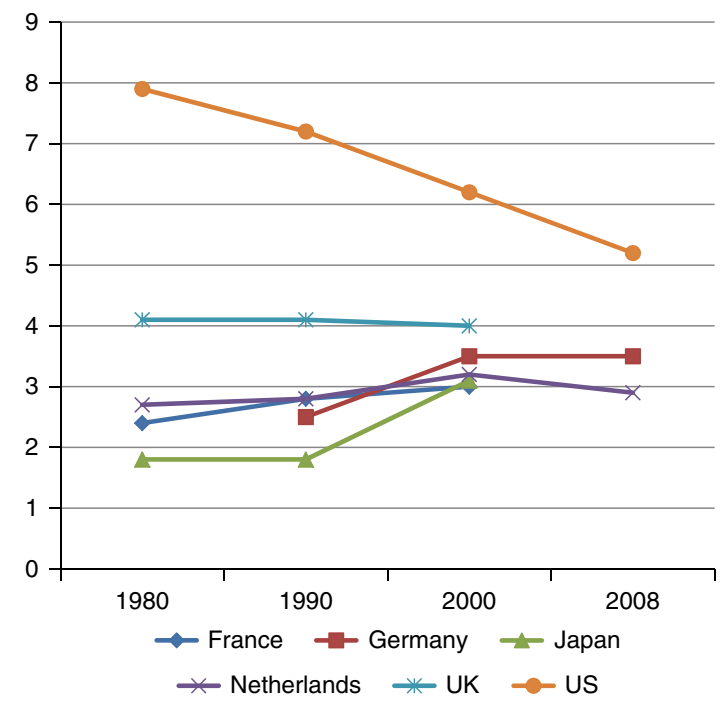

Figure 12. Divorce rates (per 1,000; ages 15-64) Source: US Census Bureau, statistical abstract of the US, 2012.

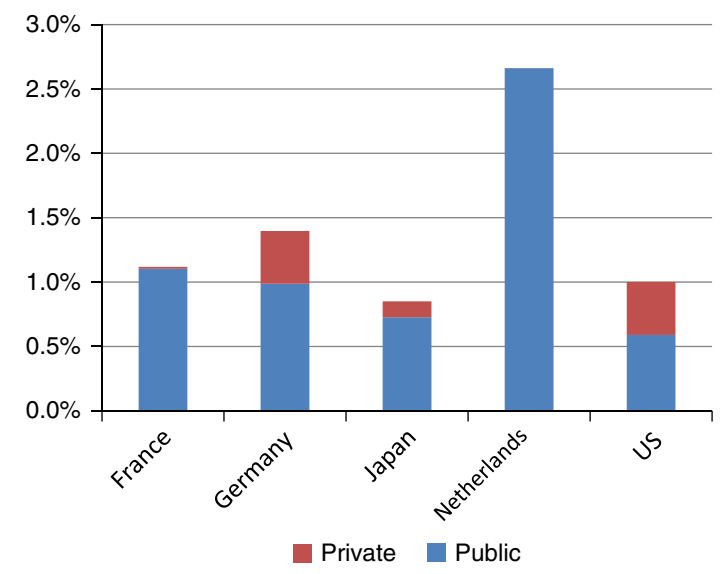

Figure 13. Public versus private expenditure on long-term care as a percentage of gross domestic product (2009)

Source: OECD stat extracts.

\section{Country Specific}

\subsection{France}

\subsubsection{Demographics}

- France, like most other developed countries, is experiencing an increased demand for LTC. The OECD projects that the cost of care will increase from around $1.4 \%$ of GDP in $2007,1.7 \%$ of GDP in 2008 to between $1.9 \%$ and $2.6 \%$ of GDP by 2050 .

- In 2010:

- France had an end-year population of 65.0 million; 


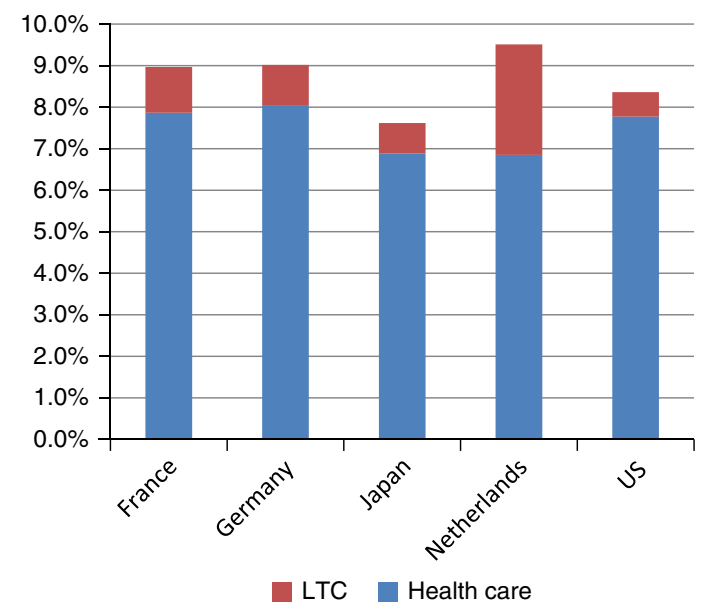

Figure 14. Public expenditure on healthcare and long-term care (LTC) as a percentage of gross domestic product (2009)

Source: OECD stat extracts.

- age $65+$ represented $16.1 \%$ of the total population;

- age $85+$ represented $2.5 \%$ of the total population;

- male life expectancy at birth was 78.1 years and 18.9 years at age 65 ;

- female life expectancy at birth was 84.8 years and 23.4 years at age 65 .

- In 2050:

- France's projected population is 72.3 million;

- projected age $65+$ is $25.8 \%$ of the total population;

- projected age $85+$ is $6.1 \%$ of the total population.

- Healthy life expectancy from age 65 is estimated at 9 years for males and 9.8 years for females. Healthy life expectancy measures the number of years that a person of a specific age is expected to live without any severe or moderate health problems, which means that they can maintain usual activities.

- In all, 12 million people aged 60 and over (and a third of people aged 75 and over) live in a private home; $28 \%$ of the 12 million people aged 60 and over, i.e. 3.2 million (57\% of whom are women) are in need of help in their everyday lives. Around $75 \%$ of care spend is in institutions and $25 \%$ in the home.

\subsubsection{Public systems}

- The French LTC system is based on a mix of what the government receives through general taxation (Beveridge) and through national insurance funds (Bismark) models. The French system also relies on families to play a key role in financing and assisting with LTC. Total expenditure was estimated to be as much as €25 billion in 2007, with the OECD estimating that public expenditure is $1.7 \%$ of GDP in 2008 . France is discussing reforms and, potentially, the creation of a fifth social security pillar, so the detail below relates to the current system.

- The French system operates a decentralised model with most of the decisions being made at the "departmental" level where individuals receive a Personalised Autonomy Allocation (APA). The APA is paid to all individuals over the age of 60 who require assistance with ADL. Individuals 
then use the APA to decide what care to get and where to get it, although expenditure is supervised and only accredited or approved service providers can be hired. It is available to all individuals with no means testing for eligibility; however, the amount of benefit is reduced according to an individual's income. There is a maximum of $90 \%$ reduction for the highest earners. The monthly cash allowance varies according to the assessed level of dependence between EUR 530 and EUR 1,235 (April 2010). The Government sets a national scale for assessing individuals' needs and the departmental authorities allocate the APA according to these assessments. There were 1.1 million people in receipt of APA in 2008.

- Around $70 \%$ of the APA budget is collected through local government funding. The remaining $30 \%$ is received from the central government fund, the "National Solidarity Fund for Autonomy" (CNSA). The central government also sets the priorities for funding it provides through the CNSA. The CNSA is funded through employers' social security contributions and from general taxation. Additional funding comes from the "solidarity day" when employees donate a day's wage to fund care. In 2008 the CNSA budget totalled $€ 17$ billion.

- The APA is used to meet dependency costs only; individuals must still meet their own hotel costs. Cost-sharing for families is an important element of LTC financing. The maximum amount of APA does not cover the total costs of care and families or individuals are expected to make up the difference. In 2007 families paid $€ 650$ million in co-payments. Individuals in institutional care must meet the full costs for a room, food, etc. unless they receive housing benefits (paid by the local authority).

\subsubsection{Private systems}

- The private insurance sector developed slowly in France, but has seen larger growth in recent years. According to the OECD $<1 \%$ of LTC spending in France was from private insurance provision in 2007 but by $201015 \%$ of the population aged over 40 had an LTC policy. This growth has been mostly attributed to the wide discussions taking place in the media on how to fund LTC and the public becoming more aware of the risks and costs involved, and the gaps in public provision described above.

- Indemnity policies are most common and typically pay out a fixed monthly sum based on the level of dependency. Typically, they provide eligible recipients with a fixed level of monthly benefits for life, once the insured meets criteria set in the policy regarding the level of dependency and waiting period. About $20 \%$ of indemnity policies solely cover the risk associated with severe or very severe levels of dependency, while about $80 \%$ also cover the risk associated with moderate levels of dependency. A typical policy for a 60-year old would charge an annual premium payment of about EUR 400 and EUR 500 per year (2008 values) to obtain a monthly payment of around EUR 600 in the event of severe or very severe dependency and between about EUR 200 and EUR 400 a month in the event of moderate dependency. Generally, benefits would start to be paid 3 months after an insured individual qualifies for LTC. Inflation protection is generally provided with both the monthly benefit amount and the premium levels subject to annual increases.

- Some insurance policies have LTC rider benefits, where benefits are paid out of the death benefit or the accumulated savings built into the policy in the event that the policy holder requires LTC for an extended period of time. These accounted for around 5\% of the French market in 2009

- The group LTC insurance market is large, representing about $45 \%$ of the LTC insurance contracts in 2009. Employees covered under a group insurance plan are generally required to participate in the plan and employers may pay for a portion of the premium on behalf of the employees. They do not provide coverage for future risks once an individual is no longer working. 


\subsubsection{Partnerships}

- There are currently no partnership schemes for LTC in France, other than the mix of public and individual family (sometimes through insurance) can be seen as a social partnership.

\subsection{Germany}

\subsubsection{Demographics}

- Germany has high life expectancy at 77.7 years for males and 82.7 years for females (2011).

- The total population in 2011 was 81.5 million.

- Around $20 \%$ of the population was aged over 60 in 2010 with this percentage projected to exceed $30 \%$ by 2050 .

- In 2009 there were 2.4 million of the population with care needs at some level of whom 750,000 were in nursing homes and the remainder at home cared for by relatives $(66 \%)$ or by care agencies $(34 \%)$.

\subsubsection{Public systems}

- The German LTC system is a mixture of different insurance structures including both social insurance funds and private insurance schemes.

- Social insurance, based on health insurance rather than life insurance principles, was introduced as a compulsory insurance in 1995 with subsequent reform to the structure to enhance the benefits in 2008.

- In 2013 there were 70 million of the population covered by the compulsory social insurance.

- Social insurance operates on a pay-as-you-go structure.

- Benefits may be paid in cash or in kind. Roughly $60 \%$ of the total benefit cost is paid in cash.

- As an alternative to the social insurance coverage the high income earners (above $€ 49,000$ in 2011), civil servants and the self-employed may opt for private compulsory insurance coverage instead of the social insurance; 9.5 million of the population had private compulsory insurance in 2013.

- Benefit levels (2012) depend on the care needs. For nursing care the benefit varies between $€ 1,023$ per month to $€ 1,850$ per month although a higher benefit of 1,918 may be payable in hardship cases. For care in the home the benefit levels vary between $€ 235$ per month and $€ 700$ per month as a cash allowance. The benefit levels aim to cover only part of the cost.

- Additional benefits are provided for those with cognitive impairment.

- Benefit levels will be reviewed regularly.

- Social funds paid $€ 21.9$ billion in benefits in 2012 with roughly half for home care and half for care in a care facility. There were 2.4 million beneficiaries.

- In 2013 contributions to the social insurance are $2.05 \%$ of income or $2.3 \%$ if aged between 23 and 65 with no children of which $1.025 \%$ is paid by the employer. The percentage applies on earnings up to a maximum of $€ 3,937.5$ per month.

- Contributions to the private compulsory insurance vary by age from $€ 18.87$ per month at age 30 to $€ 59.51$ per month (from 2010) with $50 \%$ paid by the employer.

\subsubsection{Private systems}

- Private insurers offer products on both a life insurance basis and a health insurance basis. 
- Life insurance products were introduced from 1985 on a stand-alone basis covering LTC annuities in conjunction with pension and death benefits. From 1992 a further generation of products were offered including waiver of premium benefits, immediate LTC annuities and deferred LTC annuities. Total policies numbered under 140,000 by 2009 .

- Health insurance products were also introduced in 1985 providing daily cash benefits and/or reimbursement of LTC cost. From 1994 further products were introduced to provide top-up benefits of additional cost reimbursement and services to the compulsory LTC insurance benefits. Total policies numbered just over 1,600,000 by 2009 .

\subsubsection{Partnerships}

- The structure of the provision for LTC does enable both public and private systems to exist together but the private system sits alongside, rather than integrated with the public system.

\subsection{Japan}

\subsubsection{Demographics}

- Japan has high life expectancies and low birth rates which combined leads to an ageing population. The dependency ratio has also increased from 9\% in 1960 to 35\% in 2010 (almost quadrupling).

- Informal care at home is also reducing which is putting greater pressure on formal care.

- In 2010:

- Japan had a mid-year population of 127.6 million;

- age $65+$ represented $23 \%$ of the total population;

- age $85+$ represented $3 \%$ of the total population;

- male life expectancy at birth was 79.6 years and 18.9 years at age 65 ;

- female life expectancy at birth was 86.4 years and 23.9 years at age 65 .

- In 2050:

- Japan's projected mid-year population is 107.2 million;

- projected age $65+$ is $40 \%$ of the total population;

- projected age $85+$ is $12 \%$ of the total population.

\subsubsection{Public systems}

- Japan now has five social insurance programmes which cover medical care, pension insurance, unemployment, occupational accidents and LTC.

- Providing care and public assistance to the elderly is seen as a national responsibility in Japan.

- Japan created its LTC social insurance programme in 2000 (LTCI) responding to the difficult demographic challenges such as high life expectancies, low birth rates and a restrictive immigration policy. It covers home care and institutional care but there are no cash benefits. It is a nationally administered programme where the price and benefits are set by the national government but the assessments are made locally.

- Their reforms were aimed at meeting the following key objectives:

- increasing the level of independence for the frail elderly;

- reducing the burden of home care on their families; 


\begin{tabular}{|l|l|l|}
\hline Level & $\begin{array}{l}\text { Benefit ceiling per } \\
\text { month for } \\
\text { government } \\
\text { funding }(¥, \mathfrak{\Sigma})^{\star}\end{array}$ & Description of typical needs \\
\hline Support level 1 & $49,700(391)$ & $\begin{array}{l}\text { Almost independent; may need some } \\
\text { assistance to maintain independence } \\
\text { and prevent deterioration }\end{array}$ \\
\hline Support level 2 & $104,000(819)$ & Needs some support with ADLs \\
\hline Care level 1 & $165,800(1,306)$ & $\begin{array}{l}\text { Requires support with ADLs and } \\
\text { some care }\end{array}$ \\
\hline Care level 2 & $194,800(1,534)$ & $\begin{array}{l}\text { Requires care at level 1 and support } \\
\text { with more ADLs }\end{array}$ \\
\hline Care level 3 & $267,500(2,106)$ & $\begin{array}{l}\text { Needs substantial support with ADLs } \\
\text { and almost comprehensive care }\end{array}$ \\
\hline Care level 4 & $306,000(2,409)$ & $\begin{array}{l}\text { Cannot live without comprehensive } \\
\text { care. Almost bed-bound }\end{array}$ \\
\hline Care level 5 & $358,300(2,821)$ & $\begin{array}{l}\text { Bed-bound. Needs comprehensive } \\
\text { care }\end{array}$ \\
\hline
\end{tabular}

* The individual is required to pay $10 \%$ of this amount

Figure 15. Assessment of care needs, benefits available and user contributions

*The individual is required to pay $10 \%$ of this amount.

- more closely aligning benefits and premiums;

- providing more comprehensive care by integrating medical and LTC programmes;

- reducing the number of hospitalised elderly.

- It is a compulsory scheme for those over age 40 and it offers access to social care for those over the age of 65 on the basis of need alone. Income and wealth are not taken into account in the assessment process. The coverage for ages 40-65 is for age-related diseases such as Parkinson's disease, pre-senile dementia or stroke.

- It provides benefits based on the level of services required. There are five levels of care with one being the lowest and five the highest. The levels are based on the amount of time necessary to provide the services. Although the assessment is predominantly computerised clinical judgement is still required. It does, however, provide clarity about eligibility and service provision for individuals (see Figure 15 for a summary).

- There is a comprehensive (predominantly computerised) assessment of medical and physical status and it is reviewed every 6 months. They vary by region and are conducted by experts appointed by local government.

- Creating a diverse provider market - they have created a diverse and large provider market with respect to community care. In reaction to the rising number of dementia cases they have developed group homes with each unit providing care for around nine people within a home-type environment.

- Ensuring quality - monitoring is largely focused on staffing numbers with detailed requirements set out by central government. Inspections have been described as "rather formalistic and paperwork oriented".

- The role of competition and integration - a large-scale integrated delivery system alongside smaller providers of services has developed in Japan. Acute care providers have extended their range of services to deliver a lot of this integrated provision.

- Mobilising the community - Japan has focused a lot of attention on dementia and now have a lot of support of volunteers and have raised the awareness thereof. 
- The role of care managers - they provide a central point of access for individuals in need of care.

- The programme is designed as a pay-as-you-go system; $90 \%$ of the cost of care (regardless of the type of service) is reimbursed provided the services are rendered by a certified provider. The remaining $10 \%$ is an out-of-pocket co-payment subject to a maximum, which can vary by income level.

- The $90 \%$ is split between a mandatory contribution from those age $40+$ and tax revenue (national and local government). The mandatory contribution varies by region and is means tested. For ages $40-64$ it is about $1 \%$ of salary and for ages $65+$ it was USD 27 per month in 2010.

- In 2009 public expenditure on LTC in Japan was $0.7 \%$ of GDP compared with private expenditure of $0.1 \%$ of GDP.

- The LTCI compulsory scheme has done well to address a lot of the unmet need, to provide support on a universal needs alone basis and to support informal carers. However, the financial stability of the model is in question under the current cost and eligibility criteria.

\subsubsection{Private systems}

- There is minimal private LTC insurance in Japan. It is mainly supplemental coverage.

\subsubsection{Partnerships}

- It is mainly a publicly funded system in Japan.

\subsection{The Netherlands}

\subsubsection{Demographics}

- In 2011 the Netherlands had a population of almost 17 million. About $15.2 \%$ of the population were over age 65 and $3.9 \%$ were 80 years and older. According to CBS by 2050 these percentages are expected to have almost doubled for those over 60 and trebled for those over 80 .

- In the Netherlands life expectancy at birth is 81 years, 1 year higher than the OECD average. Life expectancy is 79 years for males and 83 years for females (2011).

- In 2010 over 600,000 people in the Netherlands made use of LTC.

- Around 340,000 of these received this care in their own home. The remaining clients received care within an institution.

\subsubsection{Public systems}

- AWBZ (Algemene wet Bijzondere Ziektekosten/Exceptional Medical Expense Act).

- The original philosophy underlying the AWBZ was that every person in the Netherlands should be insured against the very high expenses of necessary care, which very few people could afford out-of-pocket. Experience in other countries has shown that it is difficult to solve this problem with private insurance, owing to reasons such as the unpredictable nature of future LTC costs. Over time the AWBZ scheme has expanded to cover services which cannot be described as catastrophically expensive and costs have ballooned. Debate now centres on limiting the AWBZ entitlements to the most vulnerable persons and the most necessary services. Co-payments are already so high for higher-earners that some services are only used by the less well off. Consideration is now being given to which problems the system should seek to solve.

- Incepted in 1968, The Exceptional Medical Expenses Act provides for care and support in cases of long-term ill health, handicap or old age, to everyone who lives in the Netherlands. 
- It covers home help, nursing, care, treatment and supervision in care homes, nursing homes or institutions. Care in hospitals and rehabilitation centres also falls under the Exceptional Medical Expenses Act, if the stay lasts longer than 365 days.

- The AWBZ is funded by social insurance contributions from earnings of workers $(12.5 \%$ of earnings capped at about 4,000 euros per annum for the employed), pensions of the retired and benefits of the unemployed.

- Contributions are also made to the cost of services with the level of payment based on the user's income. The system is therefore comprehensive but unlike Japan there is no cap on the copayments.

- Personal Budgets (Persoonsgebonden Budget) were introduced in 1995 to encourage:

- A person-centred approach to care with increased choice and to encourage competition between providers.

- Allow choice between in-kind care and cash benefits via a Personal Budget (for noninstitutional care)

- To allow cash benefits to be paid for care provided by friends and family.

- However, from 2002-2010 Personal Budget expenditure rose by 23\% annually (from EUR 414 million to EUR 2.2 billion), whilst the expenditure during the same period on care in-kind rose by an average of $4 \%$ annually. This led to the withdrawal of the right to Personal Budgets from 2010 from those who had not already received one and the exclusion of compensation to informal carers.

- The recent changes to the AWBZ may mean that the view held in the Netherlands that the state is the steward for the elderly is no longer financially viable and some responsibility may need to be shifted back to the individual and their family.

- Regional care offices are responsible for organising and purchasing care. The care offices are affiliated with health insurers but run no risk on buying LTC, although they are required to keep costs within the regional and national budgets and to purchase care as efficiently as possible.

- Wmo (Wet Maatschappelijke Ondersteuning; Law on Social Assistance) - an act covering social services carried out by local councils. This is not an insurance scheme and is affected by the available funds. Home help is provided under the Wmo by a fund which is not ear-marked and therefore encourages efficiency as spare funds can be diverted to other uses.

- ZVW (the Health Insurance Act) - all residents of the Netherlands are compulsorily insured according to the Zorgverzekeringswet (ZVW, Health Insurance Act), which means that he or she must take out health insurance. Individuals make income-related contributions $(6.9 \%$ of the first 32,369 euros of annual taxable income) for which they are reimbursed by their employer, although tax is payable on this benefit. Contributions for the self-employed are individually assessed by the Tax Department.

- CIZ (Centrum Indicatiestelling Zorg; Centre for Care Assessment):

- Every request for AWBZ care must be assessed by this independent organisation. There are no financial incentives; its financial position is not affected by its decisions.

- Assessment for home help (covered under Wmo) is the responsibility of the local council, which has a financial incentive to restrict eligibility. However, the majority of these assessments are also carried out by CIZ, although guidelines would be specified by the council.

- LTC expenditure has risen by $66 \%$, from just over EUR 14 billion in 2000 to over EUR 23 billion in 2010 . 


\section{Sources of payment}

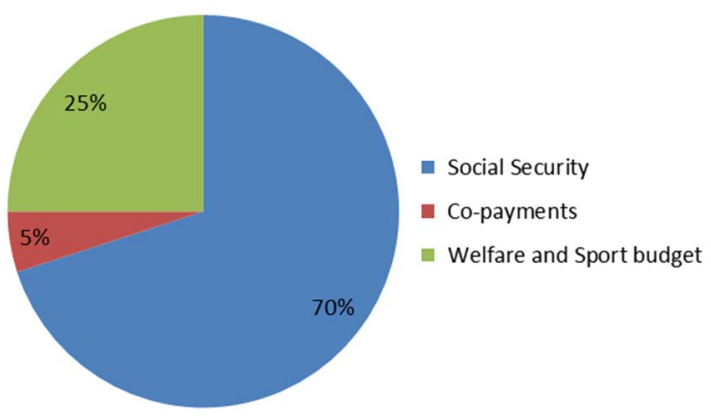

Figure 16. Sources of payment

Source: State Department of Health, Welfare and Sport.

- The Netherlands spent $3.5 \%$ of its GDP on LTC in 2008, of which $1.2 \%$ was for health-related LTC. It spent a total of $10.8 \%$ of GDP on healthcare in 2009 ranking it 23 in the world (United States $16.2 \%$ (2), United Kingdom 9.3\% (39)).

- The health- and LTC-integrated budget is approved by each new government for the following 4 years. If the budget is insufficient to meet the costs, measures must be put in place by the Ministry of Health to balance the budget.

- Cost-sharing differs between institutional and non-institutional care. Outside of institutions AWBZ beneficiaries have to pay an hourly rate for care that they receive, with an income- and age-dependent maximum. Cost-sharing for domestic help under the Wmo is structured in the same way but the council can alter the parameters within certain limits.

- There are two levels of cost-sharing for institutional care; high and low. Costs vary according to the length of time in the institution, whether a spouse is still living independently and level of income. Minimum amounts of remaining income are specified for singles and couples, which they can spend freely on clothes and incidentals.

- Sources of payment are set out in Figure 16.

\subsubsection{Private systems}

- There are currently no private systems for the provision of LTC in the Netherlands.

3.4.4. Partnerships

- There are currently no partnership schemes for LTC in the Netherlands.

3.4.5. The future

- The AWBZ has been in a state of constant evolvement since 1968. The Netherlands are in the process of introducing a number of amendments to the AWBZ and the general provision of LTC:

- Decentralisation of AWBZ to the municipal authorities (under the Social Support Act) to offer support more in tune with the client's needs.

- The transfer of the implementation of the Exceptional Medical Expenses Act from care offices to the insurer, securing a better connection between LTC and curative care, i.e. the client's insurer under ZVW will take over responsibility for contracting with the care provider, making payments and other administrative tasks. Over time the risks associated with the payments will be passed to the insurers but a Risk Equalisation System will be put in place. 
- The provision of living accommodation and care will be separated, leading to an increased possibility for clients to choose their own accommodation. Accommodation within an institution was previously covered by the AWBZ for those on a low income. This will no longer be the case; however, alternative financial assistance will be available to those in need, to assist with their housing costs.

- Simplifying the indication assessment - an indication decision will become valid for 15 rather than 5 years. There will be a reduced process for those over age 80 applying for accommodation owing to their need for care and support. The indication assessment will be centralised and uniform.

- Rehabilitation after a health shock (e.g. a stroke) is currently covered by the AWBZ, except where rehabilitation is in a specialised clinic. From 2013 this service will be covered under the ZVW.

- A budget has been reserved to allow for an annual growth in LTC of $2.5 \%$ in addition to structural investment of EUR 852 million to invest heavily in extra personnel and training.

- Funding should follow the client to a greater extent.

- Financing per treatment will change to financing based on result.

- Further professionalisation of the governance of LTC is needed.

- Rights of the client will be strengthened.

- Optimisation of the scale of care institutions to increase efficiency, lower costs and lead to a higher level of customer satisfaction and care.

- The client's need for care will take a more central position.

\subsection{United States}

\subsubsection{Demographics}

- The main data source in this section is from an organisation called "The SCAN Foundation". It is an independent charitable foundation focused on finding innovative solutions to the healthcare needs of California seniors. Its vision is to create "a society where seniors receive medical treatment and human services that are integrated in the setting most appropriate to their needs and with the greatest likelihood of a healthy, independent life".

- Their mission is to, "Advance the development of a sustainable continuum of quality care for seniors. A sustainable continuum of care improves outcomes, reduces the number and duration of acute care episodes, supports patient involvement in decision making, encourages independence, and reduces overall costs. The SCAN Foundation will achieve this mission by encouraging public policy reform to integrate the financing of acute and long-term care, raise awareness about the need for long-term care reform and work with others to promote the development of coordinated, comprehensive and patient-centric care".

- In the United States, the ageing population combined with the retirement of the baby boom generation has led to an increase in demand for LTC.

- In 2010:

- There were 40.3 million aged 65 and older (about $13 \%$ of the total US population) and 5.5 million were 85 years and older (almost $2 \%$ of the total population).

- The majority aged 65 and over are female $(57 \%)$. 


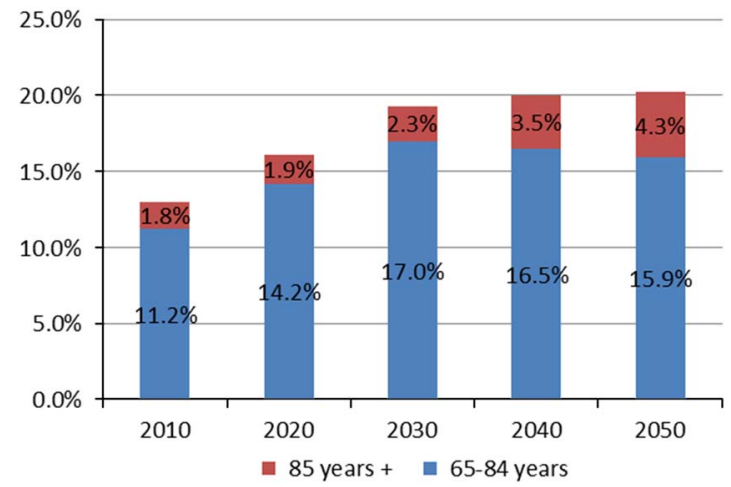

Figure 17. Older Americans as a percentage of the total US population Source: The Scan Foundation factsheet, June 2012.

- There were 53,364 individuals aged 100 and over.

- From 2009 to 2010 only about 3\% of older Americans lived in a different county or state than they had a year earlier or had moved abroad.

- About $44 \%$ age 65 and older lived alone.

- Going forwards:

- The number needing LTC is expected to increase from 12 million today to 27 million in 2050 .

- Between 2011 and 2029 about 10,000 baby boomers per day will turn 65 .

- By 2030, the number aged 65 and over is projected to be about 72 million (about $19 \%$ of the total US population).

- By 2050, the number aged 65 and over is projected to be about 89 million (about $20 \%$ of the total US population).

- Those aged 85 and older is expected to grow by more than $25 \%$ by 2030 and by $126 \%$ by 2050 .

- Figure 17 summarises these projections.

- Life expectancy has also increased and is expected to continue to increase. In 1910 life expectancy was only 52 years compared with 79 years in 2010. Life expectancy is higher for women than for men (i.e. 81 versus 76 years in 2010).

- The projections for those aged 65 and over with Alzheimer's Disease are as follows:

- 2012 - 5.2 million;

- 2025 - 6.7 million;

- 2050 - 11-16 million.

- The sources of income for those aged 65 and older in 2010 are summarised in Figure 18.

3.5.2. Public systems

- The United States has two government programmes that pay for LTC services as described below.

- Medicare is:

- Founded in 1965.

- It is a social health programme for older adults (age 65+) and younger people with disabilities, those with end stage renal failure and end-of-life care (via the hospice benefit). It spreads the 


\begin{tabular}{|l|c|}
\hline Income source & $\begin{array}{c}\text { Percentage of individuals } \\
\text { reporting income source (\%) }\end{array}$ \\
\hline Earnings from current employment & 34 \\
\hline Retirement & 48 \\
\hline Social Security & 92 \\
\hline Supplemental security & 6 \\
\hline Cash public assistance & 2 \\
\hline
\end{tabular}

Figure 18. Selected sources of income as reported by Americans age 65+ in 2010 Source: The Scan Foundation factsheet, February 2012.

financial risk (associated with illness) across society to protect everyone. It is funded through payroll tax. It provides limited post-acute care.

- It covers acute care services and pays only for medically necessary skilled nursing home and home health services. Stays in nursing homes are covered for 100 days with a co-payment for days 21-100. Home healthcare is only paid on a limited basis (i.e. only if skilled care is required). It does not pay for custodial care (i.e. personal/social care).

- To be eligible you need to have worked at least 10 years and be 65 years of age or older.

- In 2010, 48 million people were covered by Medicare with 40 million for those aged 65 and older and eight million for younger people with disabilities. It covers about half of the healthcare costs for those who are eligible.

- Medicaid is:

- Public welfare programme for the poor.

- It covers care once assets are spent down.

- The largest source of funding for medical and health-related services for people with limited income in the United States and is the primary payer of LTC services with a bias towards institutional care.

- It is a medical assistance programme jointly funded by the states and the federal government. It is funded through general taxation and is a means-tested welfare-based system.

- It is managed by the individual states and as a result differences in budgets and coverage decisions give rise to different services and spending decisions across the states.

- Those with low incomes and few assets rely on Medicaid that operates as a "safety net programme". The wealthy can afford to fund their care needs themselves or can purchase LTC insurance. Those in the middle tend to rely on informal care provision by family members or friends.

- The healthcare spending split is set out in Figure 19 and the sources of payment for LTC are set out in Figure 20.

\subsubsection{Private systems}

- Private LTC insurance in the United States provides coverage for both institutional and noninstitutional care. The claims trigger is generally based on a combination of ADL or cognitive impairment. They offer benefit periods from up to a few years to lifetime and an elimination period of 0 days up to 90 days. Their products also offer inflation protection.

\subsubsection{Partnerships}

- Previous partnership schemes were developed in the early 1990s. The intent was to encourage middle-income Americans to buy affordable LTC insurance products. In all, 40 states now offer 


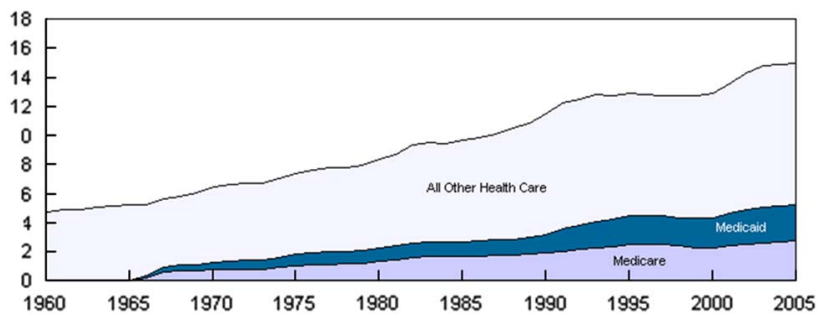

Figure 19. Healthcare spending split

Source: Wikipedia, Medicaid.

\section{Sources of payment}

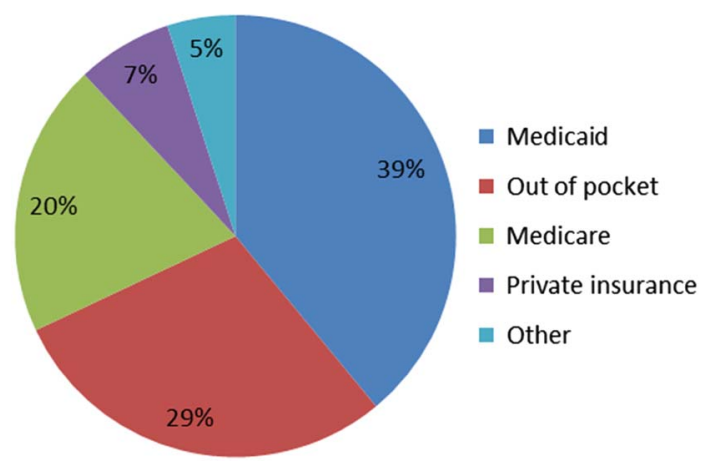

Figure 20. 2008 sources of payment of long-term care by payer (excludes informal care) Source: The Scan Foundation, 2011.

partnership products. Unfortunately, take up has struggled to exceed $10 \%$. Two models of asset protection are used as follows:

- Dollar-for-dollar (CA, IN, CT) - the amount of insurance coverage purchased equals the amount of assets protected from consideration if and when the consumer needs to apply for Medicaid (e.g. a consumer who bought $\$ 100,000$ of LTCI would get $\$ 100,000$ of care. If further care were required the individual would be able to apply for Medicaid, while still retaining $\$ 100,000$ worth of assets).

- Total asset protection (NY) - more comprehensive package as defined by the state. Initially, the state mandated that partnership policies cover 3 years of nursing home or 6 years of home healthcare. Consumers purchasing such a policy could protect all of their assets when applying for Medicaid.

- The Federal LTC Insurance Programme began in late 2002, early 2003. It provides LTC insurance to federal employees, service members and some family. There were about 270,000 insured lives at year-end of 2011 (Source: John Hancock).

- A new partnership scheme was being developed called CLASS Act. The high-level details are as follows:

- State-sponsored national workplace insurance scheme which was passed as part of the 2010 Healthcare Reform. It was to be offered by employers and paid for by employees.

- It would be a "voluntary opt-out" plan, available to most working adults and pre-existing medical conditions would not exclude individuals from enrolling, which created the problem 
of adverse selection from the start. Individuals would, however, need to have a functional impairment that was expected to last more than 90 days and required substantial assistance with two or three ADLs or have a substantial cognitive impairment.

- To receive the benefits, people would have to meet specific requirements regarding earnings and premium payments, i.e. they must have worked for 3 years and have paid premiums for 5 years.

- The benefits were very limited, e.g. \$50-\$75 per day.

- It is important to note that CLASS is not a contractual obligation in the way that private LTCI is. The provisions of the plan (e.g. costs, benefit eligibility) can be changed at any point by Congress.

- The goal was to begin the scheme in 2013; however, in October 2011, the US secretary of health and human services declared the programme to be actuarially unworkable, and work on the programme's implementation ceased. In January 2013, Congress formally repealed the CLASS Act, as part of the American Taxpayer Relief Act of 2012.

- The actuarial analysis carried out by the American Academy of Actuaries indicated that "the proposed structure and funding approaches would not be sustainable for the foreseeable future and was unlikely to cover more than a very small proportion of the intended population. The opt-out and guaranteed issue provisions posed a significant and likely risk which would either lead to increased premiums or benefit reductions in a relatively short time".

- In addition, many key details were left to the secretary of Health \& Human Services to resolve and there were considerable "devils in the details".

- One widely acknowledged benefit of CLASS was to increase public awareness about the importance of insuring against LTC risk.

\section{Applications to the United Kingdom}

\subsection{Overview of the United Kingdom}

\subsubsection{Introduction}

- The LTC environment in the United Kingdom is very complex and is currently undergoing a period of re-development as a result of the Dilnot Commission and subsequent recommendations.

- The key drivers increasing the demand for LTC are:

- expansion in the elderly population (e.g. age $65+$ is projected to more than double by 2083);

- changes in the willingness of family members to provide informal care;

- changes in the health and dependency levels of very old people;

- changes in the expectations of older consumers;

- the projected growth in the dependency ratio of this older and more infirm segment will mean the cost of providing state-funded care will become prohibitive.

\subsubsection{LTC insurance}

- The LTC insurance market in the United Kingdom has been slow to develop relative to markets like the United States and France. This is partly owing to an incorrect perception that the State will provide and a lack of clarity as to what the State does provide versus what individuals/families are responsible for. 


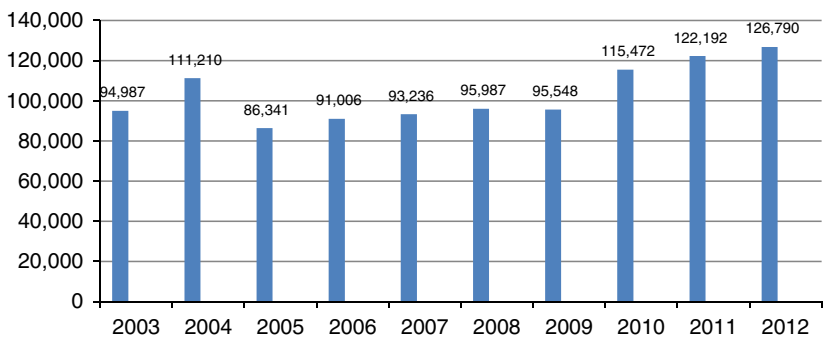

Figure 21. Immediate needs annuities sales (£000’s)

Source: ABI New Business Statistics.

\begin{tabular}{|l|c|c|c|}
\hline Calendar year & Potential market & New business & NB/potential market (\%) \\
\hline $\mathbf{2 0 0 8}$ & 160,318 & 1,157 & 0.7 \\
\hline $\mathbf{2 0 0 9}$ & 163,017 & 1,129 & 0.7 \\
\hline $\mathbf{2 0 1 0}$ & 166,686 & 1,228 & 0.7 \\
\hline
\end{tabular}

Figure 22. Comparison of new business to potential market

\begin{tabular}{|l|c|c|c|c|}
\hline & England & Scotland & Wales & NI \\
\hline Upper level & $£ 23,250$ & $£ 23,500$ & $£ 22,500$ & $£ 23,250$ \\
\hline Lower level & $£ 14,250$ & $£ 14,500$ & $£ 22,500$ & $£ 14,250$ \\
\hline
\end{tabular}

Figure 23. Means-test levels in the United Kingdom (2011/2012 levels)

- In the past there were various forms of LTC insurance, which included pre-funded, immediate needs annuities and investment bonds (i.e. unit-linked LTC insurance). Currently, only immediate needs annuities (and variations thereof) are sold. Set out in Figure 21 are the historic sales of immediate needs annuities.

- It is interesting to compare the above new business statistics with the potential market, e.g. self-funders needing residential care. This can be estimated by the following formula:

(Population age $65+) \times($ probability of entering a nursing home $)$

$\times(\%$ selffunders $) \times(\%$ to exclude Scotland, which provides free personal care $)$

- Using GAD population statistics, inception rates from the US Society of Actuaries LTC experience studies (elimination period $=0$ days and failure of 3/6 ADL) as a proxy for UK inception rates and Laing and Buisson data to determine the proportion of self-funders in nursing homes the following estimates for potential market size are derived. It indicates a market penetration of $<1 \%$ (see Figure 22).

4.1.3. The local authority financial assessment level (for those needing permanent residential care) varies in the United Kingdom as set out in Figure 23.

\subsubsection{Government activity}

- The Royal Commission on LTC for the elderly (1999) - New Labour appointed a Royal Commission on LTC for the elderly to be chaired by Lord Stewart Sutherland. In April 1998 there was a call for evidence and in March 1999 the final report was published, "With respect to old age: long term care - rights and responsibilities". The findings were contentious and not supported 
by all of the commissioners. In total the Commission made 24 recommendations; however, the focus was on two headline recommendations:

- personal care should be available after an assessment, according to need and paid for from general taxation;

- Government should establish a National Care Commission.

In January 2000 the Government responded to the Commission's report. They rejected the recommendation for free personal care but the National Care Standards Commission was set up through the Care Standards Act 2000 to begin regulating services in April 2002.

- From 2011 to present the focus has been on the "Fairer Care Funding" report published in July 2011 (which covered the funding of care) and the provision of care. The key consultation documents are summarised in Figure 24. It is important to note that although this next section on consultations applies only to England, there is a lot going on in the devolved nations that will be covered later.

\subsection{England}

4.2.1. Publications before July 2012 fed into the White Paper on social care reform, the "Draft Care and Support Bill" and the progress report on funding published on 11 July 2012 (discussed later).

4.2.2. The recommendations from the Dilnot Commission's "Fairer Care Funding” report were actively debated since their publication in July 2011.

4.2.3. The report proposed "a new partnership between the individual and the state - one where individuals need to take reasonable and appropriate responsibility, but the state provides protection for those with the greatest needs".

4.2.4. The key recommendations in the report that are relevant from a financial services perspective were:

- Capping of an individual's lifetime contribution towards social care costs. Once a cap is reached, individuals then become eligible for full State support. The suggestion for the cap was set between $£ 25,000$ and $£ 50,000$, with $£ 35,000$ considered the most appropriate and fair figure, along with a suggestion that the cap is updated annually on the same basis as the basic State Pension.

- An increase in the residential means-tested threshold, above which people become liable for their full care cost from $£ 23,250$ to $£ 100,000$. The threshold is intended to continue to act a "safety net" to help those who cannot help themselves.

- People should contribute a standard amount to cover their general living costs, such as food and accommodation, in residential care. They believe a figure in the range of $£ 7,000-£ 10,000$ per annum would be appropriate.

- Invest in an awareness campaign in plain English that people understand.

- Develop a new information and advice strategy.

4.2.5. Currently, lifetime contributions, including care and general living costs, are potentially unlimited (see Figure 25 for an illustration of these costs). 


\begin{tabular}{|c|c|c|}
\hline Date & Report & Highlights \\
\hline 11 May 2011 & Law Commission - "Adult social care" & $\begin{array}{l}\text { Recommendations about the } \\
\text { Statutory framework for the } \\
\text { commissioning \& provision of social } \\
\text { care. Recommended separate } \\
\text { statutes for England and Wales. }\end{array}$ \\
\hline 4 July 2011 & Dilnot Commission -"Fairer care funding" & $\begin{array}{l}\text { See below for further details. } \\
\text { Covered England only. }\end{array}$ \\
\hline $\begin{array}{l}14 \text { September } \\
2011\end{array}$ & $\begin{array}{l}\text { Commons Health Select Committee - } \\
\text { "Inquiry into social care" }\end{array}$ & $\begin{array}{l}\text { Considered recommendations of } \\
\text { Dilnot \& the Law Commission, } \\
\text { variations in access, personalisation, } \\
\text { barriers, economic regulation and } \\
\text { integration between health and } \\
\text { social care services. }\end{array}$ \\
\hline $\begin{array}{l}15 \text { September } \\
2011\end{array}$ & $\begin{array}{l}\text { Department of Health - "Caring for our } \\
\text { future" (covered England only) }\end{array}$ & $\begin{array}{l}\text { This engagement followed six } \\
\text { themes - quality, personalisation, } \\
\text { shaping local care services, } \\
\text { prevention, integration and the role } \\
\text { of financial services. }\end{array}$ \\
\hline 8 February 2012 & $\begin{array}{l}\text { Commons Health Select Committee - "14 } \\
\text { report on social care" }\end{array}$ & $\begin{array}{l}\text { Main recommendations focused on } \\
\text { integration of health care, social } \\
\text { care, housing and welfare and } \\
\text { Government clarification of financial } \\
\text { products and how it would work } \\
\text { with the industry to stimulate the } \\
\text { market. }\end{array}$ \\
\hline July 2012 & $\begin{array}{l}\text { Publication of White Paper "Caring for our } \\
\text { Future", "Progress Report on Funding } \\
\text { Reform" and draft "Care and Support Bill" }\end{array}$ & \\
\hline February 2013 & $\begin{array}{l}\text { Government announces introduction of } \\
\text { social care funding reforms, including } \\
\text { capped cost model from } 2017\end{array}$ & \\
\hline March 2013 & $\begin{array}{l}\text { Budget brings forwards implementation of } \\
\text { capped cost model to } 2016 \text { with cap to be } \\
\text { set at } £ 72,000\end{array}$ & \\
\hline May 2013 & $\begin{array}{l}\text { Care Bill incorporating clauses to } \\
\text { implement the Dilnot proposals placed } \\
\text { before parliament }\end{array}$ & \\
\hline $\begin{array}{l}\text { Easter to } \\
\text { summer } 2013\end{array}$ & Consultation with care sector & \\
\hline 2013-2014 & $\begin{array}{l}\text { Introduction and passage of Care Bill to } \\
\text { create legal framework }\end{array}$ & \\
\hline April 2015 & $\begin{array}{l}\text { Introduction of Universal Deferred } \\
\text { Payment Scheme and wider reform, e.g. } \\
\text { national minimum eligibility standard }\end{array}$ & \\
\hline April 2016 & $\begin{array}{l}\text { Introduction of cap \& increased financial } \\
\text { protection in residential care }\end{array}$ & \\
\hline
\end{tabular}

Figure 24. Summary of highlights

4.2.6. Figure 25 illustrates that one in four will spend very little on formal social care but one in ten will spend more than $£ 100,000$.

4.2.7. Using the lifetime contribution cap of $£ 35,000$ for social care, a $£ 10,000$ contribution for general living costs, the increased means test of $£ 100,000$ and the increased number of assessments the commission estimated that its proposals would cost the State $\sim £ 1.7$ billion, which is $<2 \%$ of 


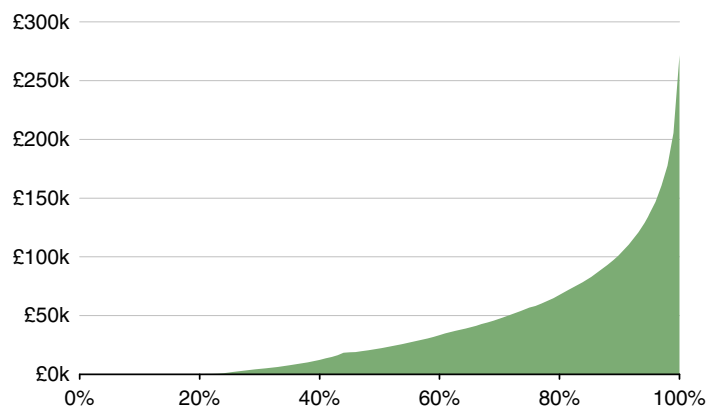

Figure 25. Expected future lifetime cost of care for people aged 65 in 2009/2010, by percentile (2009/2010 prices). Source: "Fairer care funding" report, 13

NHS funding ( $£ 100$ billion). This figure prompted speculation that the Government might hold back on accepting the recommendations.

4.2.8. However, regardless of what legislative reform follows, the care funding issue for individuals (especially self-funders) will still be there and potentially quite significant. For example, assume the individual lifetime contribution towards the social care cap is $£ 72,000$ and the individual per annum contribution towards general living costs is $£ 12,000$ per annum. The local authority is responsible for the assessment and they determine that the cost to place an individual in a care home is $£ 30,000$ per annum; therefore, $£ 18,000$ is deemed to be social care costs (i.e. $£ 30,000-£ 12,000$ ), which contributes towards the cap.

4.2.9. If the individual decides on a care home that costs $£ 30,000$ per annum then the cap would be reached in 4 years (i.e. $72,000 / 18,000=4$ ). In year 5 and onwards the State would pay $£ 18,000$ per annum and the individual $£ 12,000$ per annum.

4.2.10. If, however, the individual chooses a care home that costs $£ 40,000$ per annum, the cap would still be reached in 4 years but from year 5 and onwards the State would pay $£ 18,000$ per annum (like above) and the individual would have to pay the remaining $£ 22,000$ per annum (i.e. they pick up the additional general living costs arising from a better quality care home).

4.2.11. It is also important to understand the significant role of the local authorities post-Dilnot. They will be responsible for carrying out the care assessment, the means-test assessment, determining the contribution towards the cap and metering the cap.

\subsubsection{Industry response to the 2011 consultations}

- In response to the consultations, the key messages coming from the financial services industry were the need for reform and the need for clarity and consistency in the system. This is crucial to enable and encourage people to plan and prepare for their care and support needs.

- The concept of a cap has been viewed favourably as it gives people an amount to plan for; however, there needs to be certainty about the level of the cap. In general, a higher cap would mean more expensive premiums, but potentially greater consumer engagement with insurance. A lower cap may mean lower premiums but lower consumer engagement. 
- Any new product development needs to be very flexible to support the different needs of consumers. Private insurance could take many forms such as immediate needs annuities (which are currently available), pre-funded insurance, a link to pensions (e.g. disability-linked annuity) and a link to housing wealth using equity release as a funding mechanism. Private insurance could also cover any additional LTC needs above the cap, e.g., funding living costs or the additional costs of a more expensive care home. It is important to note that the public perception is that the cap will include the "hotel" costs; therefore, the industry needs to play its part in getting the message across about how much the individual still will need to pay even after Dilnot.

\subsubsection{Responses to the Law Commission and the Dilnot recommendations (2012)}

- On 11 July 2012 the Department of Health published three papers. The proposals are the most radical reform to social care since 1948. The papers were "Caring for our future: reforming care and support (the White Paper)", "Draft Care and Support Bill" and "Caring for our future: progress report on funding reform".

- "Caring for our future: reforming care and support (the White Paper)"

The White Paper sets out the vision for a reformed care and support system - transforming it from a service that reacts to crises to one that focuses on preventative care and is built around the needs and goals of people. "Dignity and respect" will be at the heart of the reform.

The new system will:

- focus on people's well-being and support them to stay independent for as long as possible;

- introduce greater national consistency in access to care and support;

- provide better information to help people make choices about their care;

- give people more control over their care;

- improve support for carers;

- improve the quality of care and support;

- improve the integration of different services.

- "Draft Care and Support Bill"

This Bill creates a single law for adult care and support, replacing more than a dozen different pieces of legislation. It provides the legal framework for putting into action some of the main principles of the White Paper, "Caring for our future: reforming care and support", and also includes some health measures (e.g. Health Education England, Health Research).

- "Caring for our future: progress report on funding reform"

This report sets out that the Government agrees to the principles of the Dilnot Commission's model financial protection through capped costs and an extended means test - would be the right basis for any new funding model. It is the government's intention to base a new funding model on the principles if a way to pay for it can be found. However, whilst it is the right thing to do, given the size of the structural deficit and the economic situation the country faces, the government is unable to commit to introducing a new system at this stage. Funding reform needs to be considered alongside other priorities and the right place to do this is at the next Spending Review. Decisions will be taken then. The Government will continue to work with stakeholders to consider in more detail variants under the principles of the Dilnot Commission's model, before coming to a final view at the next Spending Review.

At the last Spending Review the Government took the decision to prioritise adult care and support by allocating an additional $£ 7.2$ billion to the system over the 4 years to 2014/2015 to support local authorities in delivering care. They are now making available an additional $£ 300$ million 
over 2013/2014 and 2014/2015 to support local areas to further develop innovative, integrated services that support care and support and benefit people's health and well-being.

They are introducing a Universal Deferred Payments scheme for residential care from April 2015. The "Draft Care and Support Bill" includes the necessary powers to implement the scheme (subject to parliamentary agreement). This will extend the current discretionary scheme to a full national offer. Currently local authorities cannot charge interest, but the Government agrees that interest or charges should apply and the draft Bill will allow this. In 2013 and 2014, they will work with the care sector on how the scheme would work, including exactly when someone should be eligible and what interest or charges would be appropriate.

They are introducing a national eligibility threshold for adult care and support from April 2015. The "Draft Care and Support Bill" includes the necessary powers to implement the scheme (subject to parliamentary agreement).

They have committed to providing a clear, universal and authoritative source of national information about the health and care and support system, setting up an expert working group with financial services and the care sector to ensure the right information is available to help people plan ahead for later life and clarifying the tax treatment of disability-linked annuities. Guidance has been issued but further clarification is still required.

The White Paper will take forward portability of care assessments, legislating to transform the support for carers, by extending the right to a carer's assessment and provide an entitlement to public support and publishing a framework for improved integration between health and care.

\subsubsection{Conclusions}

- The need for people to make provision for their care and support needs is going to be a major theme for the financial services industry going forward. The Dilnot report has been a long time coming and it is hoped that the recommendations will stimulate policy makers to revitalise the market in new directions, which in turn needs to build confidence within financial services companies to invest in scarce capital. The onus now has switched to the Government to shape the reports and proposals into a structure capable of meeting the needs of generations to come.

\subsection{Northern Ireland (NI)}

4.3.1. The population of NI in 2010 was 1.8 million and is projected to increase to 1.9 million in 2020 and 2.0 million in 2036. The age $65+$ population is projected to increase from 273,000 in 2012 to 344,000 in 2022 . The corresponding figures for age $85+$ are 33,000 and 48,000 (Source: NI Statistics \& Research Agency).

4.3.2. The health and social care services are in the process of being transformed in NI as a result of the significant and growing pressures on the health and social care system, including a growing and ageing population.

4.3.3. In June 2011, the Minister for Health, Social Services and Public Safety, Mr Edwin Poots, MLA, announced a review of the provision of health and social care services in NI. A Review Team of independent experts was assembled, chaired by John Compton, Chief Executive of the Health and Social Care Board. They were asked to bring forward recommendations for the future shape of services. 
4.3.4. TYC - the ten major areas of care that were examined by the Review Team were:

- population health and well-being;

- older people;

- people with long-term conditions;

- people with a physical disability;

- maternity and child health;

- family and child care;

- people using mental health services;

- people with a learning disability;

- acute care;

- palliative and end-of-life care.

4.3.5. The areas of particular interest for adult social care are "older people" and "palliative and end-of-life care".

4.3.6. With the individual at the centre of the future care model the team looked at how changes could be made across different "POC" to deliver the vision.

4.3.7. There were 99 recommendations in their report "Transforming your care - a review of health and social care in Northern Ireland" (issued 13 December 2011), with a number of key areas emerging:

- more diverse provision of services, delivered closer to home;

- a focus on delivery of services through "ICP"

- reconfiguration of the hospital network to ensure safe, resilient and quality services into the future;

- greater personal choice and control for patients;

- greater use of technology;

- increased involvement and role for the independent, voluntary and community sectors.

4.3.8. The report used a series of case studies to illustrate the future care model. One of the case studies was for "older people", which focused on a more joined up assessment of needs and more control over an individual's own budget.

4.3.9. The review proposed a model of health and social care that would drive the future shape and direction of the service and puts the individual at the centre with services becoming increasingly accessible in local areas. The proposed model is set out in Figure 26.

4.3.10. The main sections of the proposals impacting on adult social care were "adult people" and "palliative and end-of-life care".

4.3.11. Under "older people" the main recommendations were:

- Home as the hub of care for older people, with more services provided at home and in the community.

- A major reduction in residential accommodation for older people, over the next 5 years. 


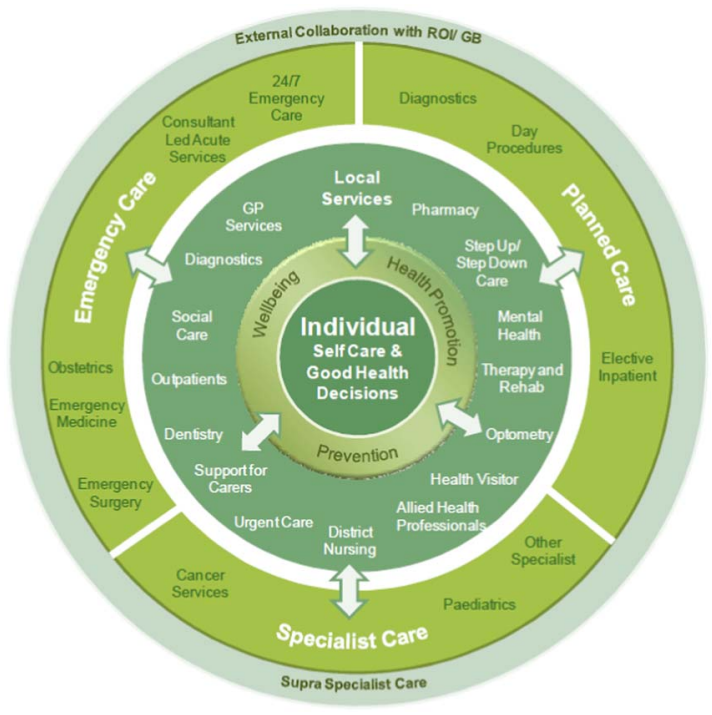

Figure 26. Transforming your care model of health and social care Source: Department of Health, Social Services and Public Safety, transforming your care website.

- Introduction of reablement to encourage independence and help avoid unnecessary admissions of older people into hospital.

- A greater role for nursing home care in avoiding hospital admissions.

- More community-based step-up/step-down and respite care, provided largely by the independent sector.

- A focus on promoting healthy ageing, individual resilience and independence.

- More integrated planning and delivery of support for older people, with joined up services and budgets in health and social care, and pilots to explore budgetary integration beyond health and social care.

- A holistic and consistent approach to assessment of older people's needs across NI and an equitable range of services.

- A diverse choice of provision to meet the needs of older people, with appropriate regulation and safeguards to ensure quality and protect the vulnerable.

- Personalised care designed to deliver the outcomes care users and their families want, with increasing control over budgets, and access to advocacy and support if needed.

- A policy review of carers' assessments and more practical support for carers including improved access to respite provision.

- An overhauled financial model for procuring independent and statutory care, including exploring the potential for a price regulator, a certificate of need scheme and financial bonds for new entrants.

4.3.12. Under "palliative and end-of-life care" the main recommendations were the development of a register to enable speedy transfer of information required to those providing such care, enhanced support to the nursing home sector for end-of-life care, individual assessment, planning, delivery and co-ordination of end-of-life care needs by a key worker, electronic patient records, targets to reduce 
the level of inappropriate hospital admissions and people in the dying phase of an illness and palliative and end-of-life care for children considered as part of the proposed review of paediatric services.

4.3.13. The SIP describes a planned approach for the delivery of the 99 TYC recommendations over the next 3 years. The SIP provides a coherent, controlled and managed framework that brings existing programmes together and adds new ones in a well-integrated way. The draft SIP, and the Population Plans which support it, were initially submitted at the end of June 2012, after which a period of consideration and quality assurance took place, followed by a 14-week period of public consultation. A Post Consultation Report was issued in March 2013 setting out the views received during that consultation, together with the health and social care response. The final SIP was issue in October 2013 incorporating most of the above.

\subsection{Scotland}

\subsubsection{Demographics}

- Scotland has similar demographics to the rest of the United Kingdom. In 2010, Scotland had an end-year population of 5.2 million, age $65+$ represented $16.8 \%$ of the total population and age $75+$ represented $7.8 \%$ of the total population.

- In 2035 , Scotland's projected population is 5.75 million, projected age $65+$ is $24.9 \%$ of the total population and projected age $75+$ is $12.8 \%$ of the total population.

\subsubsection{Public systems}

- Scotland has a similar structure to the funding of care to the rest of the United Kingdom apart from an entitlement for over $65 \mathrm{~s}$ to get free personal care and for all ages to get free nursing care, if found eligible after a care assessment.

- Means testing for permanent residents of care homes (the capital test) - the means testing is very similar to the test within England. If an individual has capital above $£ 25,250$ (since April 2013) they are deemed to be able to pay the standard rate for care themselves out of this capital. If their capital is between $£ 15,500$ and $£ 25,250$ they make some individual contribution and below $£ 15,500$ they do not need to pay out of capital. An individual's home is taken into account in the assessment, but only if they were the sole owner living in it before they went into care, and only after they have been in care for 12 weeks. The value of the former home must be ignored for the purposes of the financial assessment the home continues to be lived in by one or more of the following - a spouse, civil partner or someone who lived with the individual as if they were married or civil partners, a relative who is aged 60 or over, a relative who is aged under 60 but is incapacitated, a child under the age of 16 whom the care home resident is liable to maintain, a divorced or estranged partner, who is a lone parent with a dependent child.

- Means testing for permanent residents of care homes (the income test) - generally pension income, from private or state sources, are included as income and will be assessed as being able to contribute towards the cost of care, including hotel costs. There is a complex assessment of pensions and savings credit that allows an individual to retain some of their savings. In addition, individuals are allowed to retain a PEA. The current rate from April 2013 is $£ 23.90$ per week and is increased annually in line with average earnings. This allowance is intended for personal items such as personal toiletries, gifts for friends and family, stationery and other minor items.

- Means testing for permanent residents of care homes (deferring the costs of residential care) deferred payments were introduced in July 2002. They allow people to avoid selling their homes 
up-front to meet their care home fees by entering into a legal agreement to have part of their fees paid by their local authority and the balance settled from their estate. They are operated individually by local authorities, but the Scottish Government sets out a national framework from which they expect the local authority to operate the scheme. They can be used to cover the hotels costs of care and also top-ups for a higher level of service than the council will provide.

- Free personal care and nursing care - since July 2002 everyone aged 65 and over, regardless of income or assets, who are assessed as needing care in a care home are eligible to claim personal care payments, which contribute towards the cost of their care. People of any age, regardless of income or assets, who need nursing care, are eligible for nursing care payments. The amount the council pay towards care costs is currently (April 2013) $£ 166$ per week for personal care, $£ 75$ per week for nursing care and $£ 241$ to cover personal care and nursing care. The local councils only need to pay this personal and nursing care once an individual has made a contract with a care home. For a "self-funder" only personal and nursing care is paid by the local authority and they have to pay hotel costs themselves, whereas the local authority would make a contribution towards hotel costs for all those failing the means test.

- Domiciliary care - individuals aged 65 and over can no longer be charged for personal care services provided in their own home. They can, however, be charged for domestic services such as help with shopping or housework but any charge would be subject to a financial assessment.

- Public expenditure - in July 2013 the Scottish government released the latest figures of take up and expenditure on free personal and nursing care, fully covering up to the end of financial year 2011-2012. The key relevant points of the report are as follows:

- Care homes - there were just under 30,750 people aged 65 and over in care homes in 2011-2012. This represents $3.5 \%$ of the population aged 65 and over. This number has gone down by around 1,300 since 2003-2004. The number of people in Scotland receiving FPNC payments to help pay their care home fees increased steadily since its introduction in 2002 . In 2011-2012 there were nearly 9,700 people receiving free personal care payments, compared with 8,350 in 2003-2004. This represent about a third of care home residents. Around twothirds of people receiving the free personal care payments also receive the free nursing care payment (just over 6,000 residents in 2011-2012). The remaining two-thirds of residents in care homes are fully publicly funded. These residents contribute to their care home fees from their pensions and any other income they may have and the local authority funds the balance which will be greater than the free personal and/or nursing care payments received by selffunding residents. In 2011-2012 net expenditure in care homes for older people was $£ 636.9$ million. Of this $£ 88.2$ million was spent on free personal care payments for self-funders, and $£ 23.2$ million on free nursing care for self-funders. This total on free personal and nursing care has risen from $£ 86$ million in 2003-2004, out of a total of $£ 429.8$ million.

- Home care - in 2011-2012 there were 51,120 home care clients, representing 5.9\% of the population aged 65 and over. Of these, 46,740 were receiving personal care services, around $5.3 \%$ of them aged 65 and over population. This has risen from 32,870 in 2003-2004. As mentioned above, since July 2002, local authorities in Scotland can no longer charge for these services. This large increase in people receiving services in their own homes reflects an increasing older population and a move away from LTC in hospital and care homes towards providing care in a person's own home for as long as possible. In addition to the increase in numbers receiving personal care at home, the average hours an individual receives has increased from 6.9 to 8.2 per week between 2003-2004 and 2011-2012. In 2011-2012 net expenditure on home care services for individuals aged 65 and over was $£ 397.6$ million, with 
$£ 346.7$ million of this on personal care at home. This compares with a total in 2003-2004 of $£ 223.8$, with $£ 132.8$ million on personal care. The Scottish government believes that more than doubling of spend on free personal care since its introduction is reflected in the shift away from care being provided in either care homes or hospitals towards more care being provided in people's own homes. At the same time there has been an increase in the proportion of clients receiving personal care services as home and care workers are increasingly providing personal care services rather than domestic services.

4.4.3. Private systems - Scotland currently has the same insurance products as the rest of the United Kingdom, with immediate needs annuities being the only actively sold products at this time. With the introduction of the free personal and nursing care top-ups for individuals who have been assessed as self-funders it will be interesting to see if this has had an effect on the overall take up of INAs.

4.4.4. "Reshaping care for older people" - like the rest of the United Kingdom, the Scottish Government recognises the ever spiralling cost of care, particularly with the projected ageing population. It estimated that the spending on health and social care would increase from a total of $£ 4.5$ billion in 2007-2008 to $£ 5.6$ billion in 2016 from the effect of ageing alone. It therefore launched "Reshaping care for older people - a programme for change 2011-2021", which aimed to provide a long-term and strategic approach to delivering change to achieve the government's vision for future care for older people in Scotland. Within the programme document it was stated that additional resources to support care services “...might require the state to raise more money or to look at a range of options, and these options will be influenced by the UK Government's response to the recommendations of the Dilnot Commission in July 2011".

- 28 May 2013 - Scottish Care Bill

A new bill designed to ensure that health and social care systems work together effectively to improve the provision of care was published in Scotland on 28 May 2013. The bill is intended to facilitate the integration of NHS and local authority budgets, thereby reducing unnecessary delays that can keep older people in hospital longer than needed. This better integration is designed to allow Health Boards and Councils to provide the most appropriate services at the right time and to increase the amount of care that can be provided at home and reduce hospital admissions in the older age group.

- September 2013 - "Reshaping care for older people - getting on"

In September 2013 the Scottish Government published an update on the "Reshaping care for older people" change programme. Within this they stated that the programme has already been a huge success, not at least because of their partners in local government, the third and independent sectors. They recognised the issues of future demographic and economic challenges but reiterated their full commitment to free personal and nursing care. Summarising they stated, "We recognise there is more to do. We think the future shape of health and care services need to look very different from what we have in place just now. We want to see more control past to the individual. We want to shift resources away from institutional care and into community based support. And we want to make sure that we have fair funding arrangements in place that will underpin sustainable public services in the future. The demographic profile of the country is changing and this report restates our two-step solution: to optimise care arrangements through closer integration of health and social care services; and to identify the financial impact of increasing levels of need and in time lay the path towards a sustainable funding model. We look forward to working with our partners in pursuit of these twin objectives".

- Despite this progress, a recent audit Scotland report has questioned the long-term sustainability of the system, indicating that spending on health and social care for over $65 \mathrm{~s}$ will have to increase 
from $£ 4.5$ billion to $£ 8$ billion by 2031 , unless there are changes to people's well-being and the way in which services are provided. Audit Scotland said overall progress in delivering better services had so far been slow. It also found spending did not appear to be moving away from emergency and residential care and into local initiatives. The Scottish Government maintained that it was committed to ensuring the older population received the support they needed to stay in their own homes for as long as possible.

4.4.5. Lessons learned - it is clear that the rest of the United Kingdom can learn a lot from the 10 years of experience of free provision of care to the elderly, as the rest of the United Kingdom has similar demographics and financial profile of individuals. In 2006, the University of Stirling commissioned a study of the lessons that could be learned from Scotland. Some of the main conclusions and comments were:

- The introduction of free personal care did not reduce the level of informal caring.

- Differences between Scotland and the rest of the United Kingdom in the public costs of personal and nursing care are smaller than popularly assumed. In Scotland, residential clients no longer receive Attendance Allowance. In the rest of the United Kingdom, care home residents continue to receive Attendance Allowance and more generous provision for nursing care.

- Free personal care can support clients' wishes for person-centred care sensitive to individual needs.

- Confusion about the care system remained widespread among clients.

- A transfer of the free personal care policy from Scotland to the rest of the United Kingdom would not be a simple matter because of implications for other components of care provision.

- Nevertheless, the Scottish policy offers wider lessons including its affordability in relation to overall public spending, its role as a catalyst in changing the balance of care towards care at home, the need for improved co-ordination of benefits and social care systems and the positive impact for clients, particularly those of modest means.

\subsection{Wales}

4.5.1. The population of Wales was 3.1 million in 2012 and is projected to increase to 3.2 million in 2022 and 3.3 million in 2037. The corresponding age 65+ figures are 586,000 in 2012, 702,000 in 2022 and 878,000 in 2037. The age 65+ per 1,000 aged 16-64 values are projected to increase from 303 in 2012 to 368 in 2022 and 469 in 2037 (Source: National Statistics, 2012-based national population projections for Wales).

\subsubsection{Social services and social care}

- Social services are delivered by 22 local authorities and around 1,800 private and independent organisations. They support 150,000 people covering adult and child care, support and advice, grants and community voluntary care.

- The basis for the Welsh Government's Social Services and Social Care work is the 10-year strategy "Fulfilled Lives, Supportive Communities", which covers 2008-2018. It outlines that local authorities are responsible for strategic planning, arranging the provision of services to meet needs, for undertaking assessments and care management for those who need help and support and for safeguarding vulnerable adults and children.

- The strategy is intended to deliver social services that are strong, accessible, accountable, in tune with citizens' and communities' needs and promote independence and social inclusion. 


\subsubsection{Adult social services}

- Social services currently support around 100,000 adults.

- Responsibility is shared between central and local government. The local authorities have the statutory responsibility for the planning, assessment, commissioning and delivery of social services.

- Social services authorities are required to assess people who might require community care services and to decide what, if any, services meet their needs. The services range from advice and counselling to care and support in their own homes, either residential, nursing care or elsewhere.

- Informal carers provide about $70 \%-80 \%$ of all the care provided, and small changes in their contribution and commitment could have far-reaching implications for the demand on formal care services. Recent changes in legislation have enhanced support for carers, and supporting them to continue in their caring role is a key new responsibility for social services.

- Health boards and local authorities have a joint statutory responsibility to produce the local health, social care and well-being strategy. In support of this, social services departments work in partnership with the health bodies responsible for improving the health of their resident population in planning, commissioning and providing services.

- An individual with both social care and health needs should be jointly assessed by health and social services professionals working together, and a joint care plan developed and delivered. It is particularly important that, where needed, general practitioners and community nurses are involved. There are legal powers allowing local authorities and the NHS to share budgets, provide joint services and delegate commissioning.

- The overall aim is to encourage integrated planning, commissioning and delivery of services as well as to improve multi-disciplinary working, remove duplication and increase accountability.

\subsubsection{Charging for social services}

- Residential care - under the National Assistance Act 1948 local authorities are required to arrange for the provision of residential care (in a residential home or a nursing home) to individuals assessed as requiring care and who meet the local authority's eligibility criteria. Details are set out below:

- Under the National Assistance Act 1948, local authorities are also required to charge for the accommodation and personal care they arrange. The aim is then to recover as much as possible the costs whether directly provided or with an independent home.

- The Act also means that local authorities have the legal responsibility for commissioning the accommodation and personal care an individual requires. As a result, it is the responsibility of each local authority to determine the level of fees it will pay for this. The level of fees it will base upon a variety of factors; e.g., the dependency needs of residents, location and facilities of the home and the operating costs of the home.

- To ensure local authorities apply the principles of residential charging consistently, the Welsh Government has issued CRAG. This sets out the basis on which authorities should make charges but does not set the level of those charges. Under the guidance, the contribution a person makes to their residential accommodation and personal care costs is assessed by taking account income (including most benefits and pensions) and capital (such as savings, investments and the value of any property owned). Each resident will therefore undergo a financial assessment by their local authority to calculate their financial means and the level of any charges to be made. 
- In undertaking this assessment, authorities will use a single capital limit set by the Welsh Government to determine the level of local authority financial support to which a resident may be entitled. Residents with capital over the capital limit are expected to meet the full cost of their accommodation and personal care from their own money. Residents who have capital below the capital limit receive maximum financial support from their authority and only contribute whatever income is considered appropriate by the financial assessment. The capital limit is set out in CRAG and reviewed in April each year.

- When calculating a resident's charges local authorities must allow residents to keep an amount of their weekly income for their personal expenses, known as the personal expenses allowance. The PEA is determined by the Welsh Government and set out in CRAG. It is increased in April each year.

- Non-residential care - to receive such care a person must be assessed by their local authority to determine if their care needs meet the council's local eligibility criteria for services. The "Social care charges (Wales) measure 2010)" gives local councils a discretionary power to charge for these services. This became effective 11 April 2011. Where councils decide to charge adults for their non-residential social services certain arrangement must occur which include:

- Councils must issue an invitation for a means assessment (a financial assessment) to those receiving services for the first time where it plans to make a charge. They must also issue an invitation to existing service users where it plans to alter a charge as a result of a change in the service they receive or in their finances.

- Councils must undertake this assessment where service users request one and provide the information needed to do this.

- Councils cannot charge for particular services. This includes transport to attend a day service, where attending this and transport to it are included in the agreed services to be provided.

- Councils also cannot charge for providing information about their services or the charges they set for these. In addition, they cannot charge for undertaking assessments of care needs or means assessments.

- In setting charges councils must allow service users to keep at least the amount of their income support, employment and support allowance or pension credit guarantee credit plus $35 \%$ of that amount. They must also allow service users to keep a further $10 \%$ as a contribution towards their daily living costs, which may be higher as a result of a disability or medical condition.

- Councils must not take into account any money earned by a service user.

- Councils cannot set charges that are more than $£ 50$ per week for all of the services a service user receives (except where they charge a flat rate for a service such as meals).

- Councils must operate a scheme where service users can ask for charges set to be reviewed.

\section{Conclusions}

\subsection{Generic Lessons}

5.1.1. Shifting from a means-tested design to a universal model appears to be workable and quite popular in some countries.

5.1.2. LTC costs are increasing more rapidly than expected in those nations that have adopted reforms and as a result are having to cut back on benefits.

5.1.3. Reduce unnecessary hospitalisation for the elderly as has been experienced in Japan. 


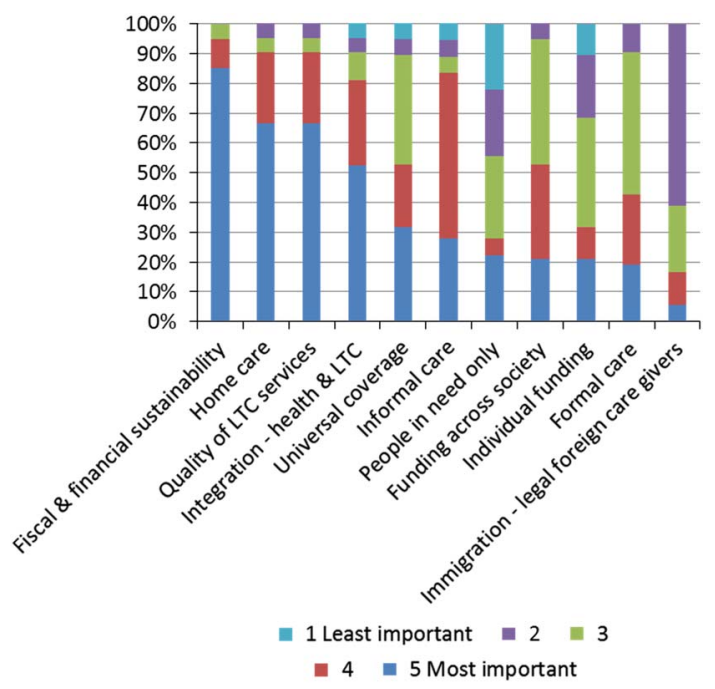

Figure 27. Policy priorities for long-term care (LTC) systems in the OECD, 2009-2010 Source: "Help wanted? Providing and paying for LTC", OECD, 2011.

5.1.4. Ageing populations with growing incidences of disabilities, looser family ties, and more twoworker households are all factors driving the increased demand for LTC. Informal care in the United Kingdom is estimated to be over $£ 30$ billion per annum assuming a national minimum wage for informal carers (Source: L\&B 2011/2012). Countries around the world must develop more comprehensive strategies to address this multi-dimensional problem. It will require reframing existing challenges in a manner that facilitates progressive change to the roles of public and private resources and fosters more innovative approaches.

5.1.5. Countries with LTC programmes that are funded primarily with public money might consider increasing public and private partnerships (through the use of private insurance or other risk-sharing arrangements). At the same time, all countries should continue to offer incentives and improve support to LTC providers and informal caregivers to ensure quality and access in the face of growing demand.

5.1.6. Figure 27 indicates that financial sustainability is the most important policy priority for LTC systems in the OECD.

5.1.7. Figure 28 summarises the universal LTC insurance schemes for three of the OECD countries studied in this paper.

\subsection{Country Specific}

\subsubsection{France}

- The strategy for the financing of care is set at a national level; however, the implementation of care is devolved to the local level, whilst ensuring a level of national consistency.

- The public/individual partnership has introduced a growing insurance market as individuals have become more aware of their own obligations to share the cost of care and have looked to indemnify themselves form burdening costs. 


\begin{tabular}{|c|c|c|c|c|c|c|c|}
\hline Country & Year & $\begin{array}{l}\text { Insurers/purch } \\
\text { asers }\end{array}$ & Financing sources & Contributions & $\begin{array}{l}\text { Eligibility to } \\
\text { benefits }\end{array}$ & Benefits & Providers \\
\hline Germany & 1995 & $\begin{array}{l}\text { LTC insurance } \\
\text { funds }\end{array}$ & $\begin{array}{l}\text { Payroll and income- } \\
\text { related contributions } \\
\text { (100\%) }\end{array}$ & $\begin{array}{l}1.95 \% \text { payroll tax (additional } \\
\text { premium of } 0.25 \% \text { for those with } \\
\text { no children). } \\
\text { Paid by all working-age and } \\
\text { retired population. } \\
\text { Divided between workers and } \\
\text { employers. } \\
11 \% \text { of population opts out of } \\
\text { social insurance and is obliged to } \\
\text { buy a private LTC plan with } \\
\text { equivalent benefits to social LTCI. }\end{array}$ & $\begin{array}{l}\text { Based on a need- } \\
\text { assessment } \\
\text { regardless of age }\end{array}$ & $\begin{array}{l}\text { In-kind or } \\
\text { cash, at } \\
\text { users } \\
\text { choice } \\
\text { Fixed value, } \\
\text { adjusted } \\
\text { periodically }\end{array}$ & $\begin{array}{l}\text { Providers on } \\
\text { contract with the } \\
\text { social LTC } \\
\text { insurance funds }\end{array}$ \\
\hline Japan & 2000 & Municipalities & $\begin{array}{l}\operatorname{Tax}(45 \%) \\
\text { Contributions (45\%) } \\
\text { Cost-sharing }(10 \%)\end{array}$ & $\begin{array}{l}\text { Paid by over } 40 \text { year old } \\
\text { population. } \\
\text { Insured individuals between } 40 \text { - } \\
64 \text { pay } 30 \% \text { of total LTC costs. } \\
\text { Income-related contributions for } \\
\text { those aged over } 65 \text { years. }\end{array}$ & $\begin{array}{l}\text { Over } 65 \text { assessed } \\
\text { as needing LTC. } \\
\text { Over } 40 \text { with } \\
\text { certain types of } \\
\text { diseases. }\end{array}$ & In-kind & $\begin{array}{l}\text { Compelling } \\
\text { services providers } \\
\text { (private } \\
\text { companies, } \\
\text { consumers' co- } \\
\text { operatives and } \\
\text { NGO) certified by } \\
\text { the government }\end{array}$ \\
\hline Netherlands & 1968 & $\begin{array}{l}\text { Regional } \\
\text { insurers } \\
\text { (private } \\
\text { insurance } \\
\text { companies) }\end{array}$ & $\begin{array}{l}\text { Payroll and income- } \\
\text { related contributions } \\
\text { Means tested co- } \\
\text { payments }\end{array}$ & $\begin{array}{l}\text { Contribution rate is based on } \\
\text { income. } \\
\text { Paid by working-age and retired } \\
\text { population (all citizens over } 15 \\
\text { years old with a taxable income). }\end{array}$ & $\begin{array}{l}\text { Disabled assessed } \\
\text { as needing LTC, } \\
\text { regardless of age }\end{array}$ & $\begin{array}{l}\text { In-kind } \\
\text { (institution, } \\
\text { home care) } \\
\text { Cash home } \\
\text { (personal } \\
\text { budgets) }\end{array}$ & \\
\hline
\end{tabular}

Figure 28. Universal long-term care (LTC) insurance schemes in OECD countries Source: "Help wanted? Providing and Paying for LTC", OECD, 2011.

- All individuals receive a sum of money from the public financing (albeit the level is based on a means test) and are therefore empowered to make their own choices on the style and level of care they receive. This also gives the government an element of control as they can vary these payments to individuals and pass on a greater share to the individual should care costs spiral out of control.

- In addition to the main care financing France has also introduced plans to tackle one specific cause of LTC need, Alzheimer's. The third Alzheimer plan was launched on 1 February 2008 by President Sarkozy, who pledged EUR 1.6 billion to the 5-year programme. The original objectives were updated and integrated into four main activity groups - improve diagnosis, provide better treatment and support, provide help more effectively and speed up research. Included within this was a budget of over EUR 1 billion to particularly tackle the care aspects.

\subsubsection{Germany}

- It is possible to create a market where both public and private provisions operate on an insurance basis. The private market has grown because it is compulsory to have private insurance if you optout of the state scheme.

- Compulsory cover can still leave scope for discretionary products or top-ups to be developed.

- Even with compulsory systems benefit contribution levels need regular review.

\subsubsection{Japan}

- With the oldest population in the world, Japan offers insights into how to meet the needs of a rapidly growing elderly population. There are, however, significant differences between the Japanese and English systems as set out below:

- Individuals seeking to access publicly funded social care in England are subject to a means test; whereas, in Japan all users (with some income-related exceptions) are required to pay 
co-payments, but LTCI is comprehensive and all those in need of care receive some financial support.

- England's eligibility thresholds are currently determined locally although the assessment takes place within a nationally set framework. The new proposals outlined in the Care Bill will mean that these thresholds will be set at a national level (like Japan).

- There is a single national computerised assessment process in Japan that is understood to be fairly transparent. In England they are aiming for a greater sense of clarity about access to care but given that personalisation and well-being are part of the assessment greater flexibility is required in deciding how needs should be met.

- The governments in England and Japan have both stepped in to try and address the market failure of private LTC insurance. However, to date the sector response in England has been uncertain.

- Other points of interest for England include:

- Public support for change - this was aided by the decision to develop an insurance scheme which was deemed to be more transparent than increases in general taxation; an initially generous eligibility criteria and only the over 40 s to pay premiums. However, the benefits have now been tightened and new hotel charges have been introduced (like the proposed England model). Further adjustments are likely to be made.

- Reforming eligibility - the national thresholds for eligibility offer clarity regarding entitlement and are relatively transparent. England's means test and the rules around the introduction of a lifetime cap means that an estimated one in eight will receive state support (Source: Caring for an ageing population; points to consider from reform in Japan, Nuffield Trust, 21).

- Developing a market (competition and integration) - the government in Japan has attempted to stimulate community-based care through tightly controlled fee schedules and by allowing profit making among providers in a short period of time. Acute providers have also been encouraged to join that resulted in some new provision.

- The role of the care manager - they play a central role in the Japanese LTCI system. They are key to the delivery of a co-ordinated care package. Initially, this role was carried out by a qualified nurse (as opposed to a non-clinical worker who may not have the right skills) but the majority of managers are now non-clinical owing to the low pay. It raises the question that perhaps care managers need to be qualified nurses for only those cases with the most complex care needs.

- Quality of provision - Japan has a regulatory system of monitoring. The quality of community and home care relies largely on choice and competition; however, this may be limited as it is the care manager (who is employed by an individual provider) who guides the decision-making process. Formal quality monitoring and inspection focus mainly on staffing levels and training. Their measures of quality are more narrowly defined and are fewer than in England.

- Reducing the number of hospitalised elderly.

- Integrating medical care and LTC.

- Even retired people contribute to it so it is not only the employees and employers.

\subsubsection{The Netherlands}

- One of the most important strengths of the system is that every resident of the Netherlands is insured against situations involving catastrophic expenses. This makes LTC accessible for people who need it. 
- People do not have to save a large amount of money for LTC expenses, or spend down when they become care users, or fear they may become destitute in their old age.

- Through AWBZ, the risks are shared between people who need a large amount of LTC over their lifetime and persons who need a small amount.

- An important weakness in the system relates to the lack of incentive for efficiency, which has contributed to doubts over future sustainability.

\subsubsection{United States}

- Integration of the financing of acute and LTC.

- Co-ordinating comprehensive and patient-centric care.

\section{Glossary/Abbreviations}

Activities of daily living (ADL): include washing, dressing, mobility, toileting, feeding and transferring. Often they are referred to as "personal care".

CLASS Act: Community Living Assistance and Support Systems.

CRAG: Charging for Residential Accommodation Guidance (Wales).

Custodial, personal, social care: assistance with activities of daily living.

Deferred period: also referred to as an elimination period. It is the period of time and individual needs to pay for their own LTC before the insurance benefits commence.

Formal care: includes all care services that are provided in the context of formal employment regulations, such as through contracted services, by contracted paid care workers, declared to social security systems.

FPNC: free personal care and/or free nursing care.

GAD: Government Actuaries Department.

Informal carers: is used often to refer to family carers, but strictly speaking this category also includes "paid" caregivers who are undeclared to social security and therefore work outside the context of formal employment regulations.

ICP: Integrated Care Partnerships.

Institutional care: nursing home/residential care.

Instrumental activities of daily living: include help with housework, meals, shopping and transportation. They can also be referred to as "domestic care or home help".

Long-term care (LTC): in the main refers to the support provided to the elderly as they lose the ability to look after themselves. It is a combination of medical, nursing, custodial, social and 
community services designed to help people who have disabilities or chronic care needs, including dementia. Services may be provided in the person's own home (i.e. domiciliary), in the community, in assisted living facilities or in care homes.

Non-institutional care: home care.

PEA: personal expenses allowance.

POC: programmes of care.

PHA: Public Health Agency.

SIP: Strategic Implementation Plan (NI).

Skilled care: qualified nursing care.

TYC: transforming your care (NI).

\section{Reference}

\section{Global data sources}

International database, US Census Bureau, available at http://www.census.gov/population/international/ data/idb/informationGateway.php

OECD stat extracts, OECD, available at http://stats.oecd.org/

World Bank Group, WDI Online, World Bank Group, available at http://data.worldbank.org/ data-catalog/world-development-indicators

US Census Bureau, statistical abstract of the US 2012, US Census Bureau, available at http://www. census.gov/compendia/statab/

\section{France}

INSEE, Government of France. Bilan démographique 2010, INSEE, Government of France, available at http://www.insee.fr/fr/themes/document.asp?ref_id=ip1332\#inter1

Health in the EU27 in 2010, Eurostat, the statistical office of the European Union, available at http:// epp.eurostat.ec.europa.eu/cache/ITY_PUBLIC/3-19042012-AP/EN/3-19042012-AP-EN.PDF

OECD: help wanted? Providing and paying for long-term care, OECD, available at http://www.oecd. org/els/healthpoliciesanddata/helpwantedprovidingandpayingforlong-termcare.htm

France - National Plans for Alzheimer's and related diseases, Alzheimer's Europe, available at http:// www.alzheimer-europe.org/Policy-in-Practice2/National-Dementia-Plans/France\#fragment-1

\section{Germany}

Federation of Private Health Insurance (PKV), available at https://www.pkv.de/

\section{Japan}

Ministry of Health, Labour and Welfare (MOHLW), available at http://www.mhlw.go.jp/english/ Statistics for life insurance in Japan, available at http://www.seiho.or.jp/english/statistics/summary/ Curry, N., Holder, H. \& Patterson, L. (2013). Caring for an ageing population - points to consider from reform in Japan, Nuffield Trust, November, available athttp:/www.nuffieldtrust.org.uk/ sites/files/nuffield/publication/131127_caring_for_an_ageing_population.pdf 


\section{The Netherlands}

Mot, E., Aouragh, A. \& de Groot, M. (2010). The long-term care system for the elderly in the Netherlands, Assessing Needs of Care in European Nations (ANCIEN), June, available at http://www.ancienlongtermcare.eu/sites/default/files/LTCSYSteminThe\%20Netehrlands_RR90. pdf

Programme letter concerning LTC, State Secretary for Health, Welfare and Sport, June 1, 2011, available at www.government.nl/.../programme-letter.../programme-letter-concerning-longterm-care-01-06-2011-tcm20-202515-1.pdf

Tinker, A., Kellaher, L. Ginn, J. \& Ribe, E. (2013). Assisted living platform - the LTC revolution, September, available at http://www.housinglin.org.uk/_library/Resources/Housing/Practice_ examples/Housing_LIN_case_studies/HLIN_CaseStudy76_Netherlands.pdf

\section{United Kingdom}

\section{England}

Adult social care, Law Commission, May 2011, available at http:/lawcommission.justice.gov.uk/ docs/lc326_adult_social_care.pdf

Fairer care funding, Dilnot Commission, July 2011, available at http://webarchive.nationalarchives. gov.uk/20130221130239/http://dilnotcommission.dh.gov.uk/files/2011/07/Fairer-Care-FundingReport.pdf

Inquiry into social care, Commons Health Select Committee, September 2011, available at http:// www.parliament.uk/business/committees/committees-a-z/commons-select/health-committee/news/ 11-09-14-socialcaretorcfe/

Caring for our future engagement, Department of Health, September 2011, available at https:// www.gov.uk/government/publications/caring-for-our-future-shared-ambitions-for-care-andsupport-2

14th report on social care, Commons Health Select Committee, February 2012, available at http:// www.parliament.uk/business/committees/committees-a-z/commons-select/health-committee/news/ 12-02-02-socialcarereport/

Elliott, S. (2012). Social care reform - a year in review, The Actuary, May, available at http://www. theactuary.com/features/2012/05/healthcare-a-long-term-view-on-social-care/

Caring for our future: reforming care and support (White Paper), Department of Health, July 2012, available at https://www.gov.uk/government/publications/caring-for-our-future-reforming-careand-support

Draft Care and Support Bill, Department of Health, July 2012, available at https://www.gov.uk/ government/publications/draft-care-and-support-bill-published

Caring for our future: progress report on funding, Department of Health, July 2012, available at https://www.gov.uk/government/publications/government-publishes-progress-report-on-socialcare-funding-reform.

\section{Northern Ireland}

Transforming your care - a review of health and social care in Northern Ireland, Department of Health, Social Services and Public Safety, December 2011, available at http://www.dhsspsni. gov.uk/tyc.htm

Strategic Implementation Plan, Department of Health, Social Services and Public Safety, October 2013, available at http://www.dhsspsni.gov.uk/index/tyc/tyc-documents.htm

NI Statistics \& Research Agency, press release, November 2013, available at http://www.nisra.gov. uk/publications/default.asp 9. htm 


\section{Scotland}

Free Personal and Nursing Care Scotland 2011-2012, available at http://www.scotland.gov.uk/ Resource/0042/00429435.pdf

Age Scotland factsheet 10s: council charging procedures for care homes, available at http://www. ageuk.org.uk/Documents/EN-GB-SC/Fact\%20sheets/Factsheet $\% 2010$ s\%20-\%20Council\%20 charging $\% 20$ procedures $\% 20$ for $\% 20$ care $\% 20$ homes.pdf

Age Scotland factsheet 46s: paying for care and support at home, available at http://www.ageuk.org. uk/PageFiles/18187/Facthseets\%202013/Factsheet\%2046s\%20-\%20Paying\%20for\%20care $\% 20$ and $\% 20$ support $\% 20$ at $\% 20$ home.pdf

Deferred payments and other funding arrangements which allow care home residents to delay selling their homes, available at http://www.sehd.scot.nhs.uk/publications/CC2004_13.pdf

Reshaping care for older people - a programme for change 2011-2021, available at http://www. scotland.gov.uk/Resource/0039/00398295.pdf, with an update available at http://www.scotland. gov.uk/Resource/0043/00434007.pdf

Lessons from the funding of long-term care in Scotland, available at http://www.jrf.org.uk/sites/files/ jrf/0036.pdf

\section{Wales}

Welsh Government Website - health and social care, available at http://wales.gov.uk/topics/health/? lang=en

2012-based national population projections for Wales, National Statistics, available at http://www. ons.gov.uk/ons/rel/npp/national-population-projections/2012-based-projections/stb-2012-basednpp-principal-and-key-variants.html

\section{United States}

The Scan Foundation, available at http://www.thescanfoundation.org/

Berdine, W. (2013). LTCI - the US market, Institute and Faculty of Actuaries Annual Health Conference, May, available at http://www.actuaries.org.uk/research-and-resources/ documents/b01-long-term-care-insuranceavoiding-potential-pitfalls-lessons-us

Actuarial issues and policy implications of a federal long-term care insurance program, American Academy of Actuaries, July 2009, available at http://www.actuary.org/files/publications/ class_july09.pdf

LTC News (2012). May, Society of Actuaries, available at https://www.soa.org/news-and-publications/ newsletters/long-term-care-insurance/pub-ltci-newsletter-details.aspx

Class Act - information on the federal class LTCI program, American Association of LTCI, available at http://www.aaltci.org/long-term-care-insurance/learning-center/CLASS-Act.php

Lin, H. \& Prince, J. The impact of the partnership LTCI program on private coverage, available at http://papers.ssrn.com/sol3/papers.cfm?abstract_id=2039059

Federal long-term care insurance program, Long Term Care Partners, available at http://www. ltcpartners.com/business_fltcip/

LTCI: from hope to change, LTC Think Tank Session, Society of Actuaries and Intercompany LTCI Conference, March 2010, available at https://www.soa.org/Files/Sections/ltc-2010-think-tank. pdf 